\title{
Intersubjetividade, Direito e Educação: Sobre a leitura hegeliana do "Direito Natural" de Fichte
}

\author{
Erick C. de Lima \\ Unicamp \\ ericklima74@hotmail.com
}

resumo 0 artigo pretende revisitar a interpretação hegeliana dos Fundamentos do Direito Natural de Fichte, não propriamente seus elementos críticos, presentes na Differenzschrift e no Naturrechtaufsatz, mas antes a possibilidade de uma assimilação positiva. Em primeiro lugar, oferecemos uma interpretação da passagem entre os $\S 3$ e $\S 4$ da obra de Fichte, entre a discussão da Aufforderung e a dedução do reconhecimento jurídico, que procura articulála como interface entre educação e direito. Na segunda parte, procuramos revelar o pano de fundo "histórico-espiritual" que permite considerar, no jovem Hegel, um embate entre formas inclusivas e excludentes de intersubjetividade. Na terceira parte, o objetivo é considerar a relação entre a eticidade, enquanto Einssein do universal e do singular, o direito e a educação. Finalmente, pretende-se mostrar que a assimilação positiva de Fichte por Hegel pode ser visualizada na articulação entre formas excludente e participativa de intersubjetividade no conceito de eticidade natural do System der Sittlichkeit, a qual sugere uma mediação entre amor e direito oferecida pela formação.

palavras-chave direito; eticidade; reconhecimento; formação; educação

\section{Educação e "redução jurídica" da intersubjetividade em Fichte}

Costuma-se dizer que a teoria da intersubjetividade do primeiro Fichte rompeu com o quadro geral da teoria da subjetividade absoluta, exposta na Wissenschaftslehre de 1794 (LAUTH, 1962), mesmo que isto não tenha se dado pela formulação de uma base ontológica comunitária para a 
subjetividade (WEISCHEDEL, 1973). A teoria da intersubjetividade no Naturrecht de Fichte está desenvolvida nos \$S 3-4, mas também, secundariamente, nos $\int S 5-7$, onde Fichte procura construir, a partir do conceito de corpo articulado, uma "teoria fenomenológica da liberdade" (RENAUT, 1986) correspondente à sua teoria do reconhecimento. No $₫ 3$, o conceito chave é o de Aufforderung ${ }^{1}$; já no $\ 4$, o fio condutor é a dedução do reconhecimento como condição da autoconsciência finita, e do conceito de direito como fundamentado nesta relação, como forma do mundo intersubjetivo na qual esta relação é fixada. Neste itinerário, também o conceito de direito é inserido no rol das condições da consciência-de-si individual.

Sabe-se que Fichte incorpora a teoria da Aufforderung na Wissenschaftslehre de 1798 (nova methodo), no contexto da dedução da individualidade e de passagem entre o eu puro e o eu individual (\$\$13-18) (DÜSING, 1986, 205 e seg.), ao passo que o enunciado do segundo "princípio doutrinário" (\$3) do Naturrecht enfatiza a necessidade de inserir a liberdade do outro como condição do processo de constituição da consciência-de-si. Pode não se tornar perfeitamente claro se a Aufforderung consiste em um ato eminentemente intersubjetivo, "que se furta à manipulação pelo sujeito que se produz espontaneamente" (HONNETH, 2001, 64), funcionando como condição exterior à consciência-de-si. Mas o fato é que, inserindo a intersubjetividade no âmbito geral de uma teoria da justiça, a teoria fichteana propicia um arcabouço conceitual capaz de reconstruir o enunciado kantiano da intersubjetividade jurídico-moral (KERSTING, 1993, 21).

O sentido maior da inserção do conceito de interpelação na encruzilhada formada pelo direito e pela "reconstrução" da auto-identidade é a aporia $^{2}$ em que se precipita a argumentação e que ameaça a dedução das condições de possibilidade da consciência individual: se a consciência tem uma primeira forma de objetivação, de reencontro consigo no não-Eu, no agir prático conforme a fins, como "atar o fio da consciência" (FICHTE, 1971, \$3) no fim tencionado, se já para a sua formulação teria sido necessária autoconsciência ? Na medida em que a ação pela qual o sujeito finito chega à consciência-de-si, sua reflexão na objetividade, é compreendida como "posterior", então a subjetividade se vê, no movimento de sua auto-certificação, despojada de sua propriedade essencial, 
de maneira que precisa ser mais uma vez pressuposta sua independência reflexiva. Neste contexto, o sujeito não é capaz de se encontrar, por meio da auto-reflexão, como determinando-se à auto-atividade < sich als bestimmend zur Selbsttätigkeit finden>, pois ele somente pode pressupor a livre auto-posição, da qual tenta se certificar reflexivamente. "É preciso ir além deste fundamento. Mas isto somente é possível se for aceito que a eficácia do sujeito esteja, num e no mesmo momento, unificada sinteticamente $<$ synthetisch vereinigt $>$ com o objeto. A eficácia do sujeito é ela mesma o objeto percebido e concebido < das wahrgenommene und begriffene Objekt>, e o objeto não é nada mais do que a eficácia do sujeito, e assim ambos são o mesmo.'(FICHTE, 1971, 32)

Para escapar à aporia, Fichte vai então apelar à apreensão de um objeto que seja ele mesmo sujeito, de maneira que, ao apreender o objeto em sua relação de limitação intrínseca, o ser racional esteja apreendendo, na verdade, sua própria faculdade prática incondicionada na figura de um outro: a intersubjetividade fornece significado preciso à idéia fichteana de que, para ser livre, a consciência-de-si efetiva tem de achar a si mesma como livre, isto é, apreender sua liberdade como objeto. "Somente por uma tal síntese nós deixaríamos de ser impelidos a uma [síntese] precedente; ela apenas conteria em si tudo o que condiciona a consciência-desi e forneceria um ponto no qual o fio da mesma se deixaria atar. Somente sob esta condição a autoconsciência é possível.'(FICHTE, 1971, 32) Tal solução indica que Fichte parece se desvencilhar, neste momento, do paradigma de uma reflexão auto-referente, para o qual o ônus de uma auto-certificação da consciência recairia sobre a própria subjetividade monológica, sendo levado, assim, a compreender a autocertificação da subjetividade como "reação a uma expectativa intersubjetivamente mediada, de maneira que a tarefa paradoxal de uma instantânea auto-reflexão se torna, como tal, obsoleta."(HONNETH, 2001, 71) A compreensão da Aufforderung constitui-a como um híbrido, um fato que possui o caráter de um acontecimento espaciotemporal, mas figura no escopo de uma dedução transcendental das condições de possibilidade da consciência-de-si (SIEP, 1992, 45). Entretanto, este enveredamento por uma "constituição intersubjetiva da subjetividade" possui estreita conexão com o programa fundamental do Naturrecht, qual seja: mostrar que o “vínculo jurídico" é uma condição necessária da consciência-de-si. 
"O que foi exposto através dela [a saber, da síntese E.C.L] deve ser um objeto; mas é o caráter do objeto que a livre atividade do sujeito seja posta, pela sua apreensão (Auffassung), como obstruída. Este objeto deve ser uma eficácia do sujeito. Porém, é o caráter de uma tal eficácia que a atividade do sujeito seja absolutamente livre e se determine a si mesma. Aqui, ambos os caracteres devem ser conservados e nenhum deles ser perdido. Com pode ser isso possível? Ambos são completamente unificados, se nós pensarmos um ser-determinado do sujeito à autodeterminação, uma solicitação (Aufforderung) a ele em resolver-se por uma eficácia.”(FICHTE, 1971, 32)

Concretamente, na medida em que consiste em um objeto a ser apreendido como limitação de uma livre eficácia, a procurada síntese somente pode ser compreendida como "expectativa do objeto" a uma resposta pautada por liberdade, pois somente assim "a eficácia do sujeito é, ela mesma, o objeto percebido e concebido.”(FICHTE, 1971, 32) O agir pela formulação prévia de fins somente pode ser primeiramente suscitado, se se depara com um "objeto" que tenciona obter uma "resolução autônoma" por parte do sujeito. Em outras palavras, a autoconsciência prática do indivíduo é compreendida, em sua gênese, como assunção pelo sujeito de uma atitude performativa suscitada pela postura "inclusiva" do objeto ou pela expectativa do mesmo por uma "resolução autônoma". Que a teoria da interpelação tencione reconstruir a experiência do indivíduo que vai se certificar de si como autoconsciência finita e que, portanto, a interpelação se refira à reconstituição da atitude performativa, à qual é conduzido o sujeito pelo encontro com um objeto que lhe concede o espaço para uma resposta não-coagida ${ }^{3}$, Fichte deixa claro quando distingue esta reconstrução da "experiência da consciência" do ponto de vista propriamente especulativo-transcendental da doutrina do eu absoluto (FICHTE, 1971, 33). Deve-se, no entanto, perceber a diferença entre a reconstrução do movimento de autoposição do eu absoluto e o movimento de constituição do indivíduo como autoconsciência, mudança de registro que permite interpretar, seguindo Siep, a auto-constituição do indivíduo como forma prototípica do método hegeliano de "rememoração" dos estágios de "experiência da consciência” (SIEP, 1991). 
Com o zweiter Lehrsatz da Grundlage des Naturrechts, o sentido em que se compreende "objeto" leva a uma modificação na compreensão da eficácia do sujeito que deve ser refletida pelo "objeto": na relação entre interpelador e interpelado, o objeto, que se tornou agora também um sujeito, lança uma expectativa quanto à livre cooperação em vista de fins comunitariamente válidos ou normas. No paradigma interativo, o sujeito não representa mais a auto-determinação, cuja execução lhe fornece a certificação de sua subjetividade, como contraposição causal a um objeto (FICHTE a Reinhold, III, 2, 386), mas como atitude performativa em relação a outro sujeito. $O$ outro sujeito somente pode se tornar consciente de sua própria subjetividade, se a expectativa erguida pelo primeiro sujeito for o reflexo de sua atividade, isto é, uma determinação que tem por fim solicitar ao outro uma expressão de sua liberdade, de fazer uso dela no mundo efetivo, de se portar como sujeito racional. Fichte chama de Aufforderung esta interação fundamental que solicita ao sujeito que faça uso de sua liberdade, que tome uma atitude performativa que é condição para a cooperação, em vista da consecução de fins comuns ou fins próprios que supõem aquiescência do outro, e que acaba por despertar nele a consciência de que é um ser livre, um indivíduo, um sujeito. "Mas o mesmo [o exigido e que é um objeto] não é compreendido de outra forma - e não pode ser compreendido de outra forma - a não ser como uma simples interpelação $<$ Aufforderung $>$ do sujeito ao agir. Tão certo [como], portanto, o sujeito compreende o mesmo, da mesma forma ele possui o conceito de sua própria liberdade e independência, e, na verdade, como de algo dado a partir de fora." (FICHTE, 1971, 32/33)

Em termos pertinentes para a Wissenschaftslehre de 1794, faz-se necessário então um choque exterior capaz de pôr o indivíduo numa situação tal que este possa obter um primeiro conceito de sua própria autonomia, no momento mesmo em que se põe em relação com um objeto que a limita. Sem dúvida, a caracterização da interpelação como "choque exterior" conduz à compreensão do conceito de Aufforderung como um nexo intersubjetivo que não pode ser reconduzido a uma gênese auto-referente da consciência, isto é, como indisponível para o indivíduo apartado. "Como o sujeito é capaz de encontrar a si mesmo como um objeto? Para achar a si mesmo, ele podia apenas se encontrar

doispontos, Curitiba, São Carlos, vol. 4, n. 1, p. 63-106, abril, 2007 
como atuante por si <selbsttätig>. Afora isso, ele não se encontra ... para encontrar a si mesmo como objeto (da sua reflexão) ele não podia se encontrar como se determinando à auto-atividade ... mas somente como determinado a isto por meio de um choque exterior, o qual tem, todavia, de lhe deixar sua inteira liberdade para a auto-determinação.”(FICHTE, 1971, 33) Ao fornecer ao sujeito uma primeira representação de sua própria liberdade, tornando o regresso infinito desnecessário, um tal "objeto" somente pode ser um outro sujeito na tentativa de estabelecer com o primeiro, seguindo sua expectativa de uma resposta racional e lhe "concedendo" a prerrogativa de uma reação não coagida, uma "comunicação recíproca <wechselseitige Mitteilung>” (FICHTE, 1971, 81). Nesta forma de comunicação, que se pauta, em geral, pela não-coação e que cria condições para uma cooperação futura, o sujeito original compreende-se, "pela primeira vez", como solicitado pelo mundo circundante a demonstrar empiricamente sua auto-atividade. Qualquer que seja a reação efetiva, exige-se do sujeito, no momento mesmo da deliberação da conduta a ser assumida em face do outro, uma simultânea auto-certificação da própria liberdade. A interpelação, "a forma particular desta eficácia recíproca" < die besondere Form dieser freien Wechselwirksamkeit $>$, é, de acordo com o argumento de Fichte, a "forma transcendental" da interação, já que qualquer outra postura do "objeto-sujeito", redutível à simples contraposição ou à relação causal entre objeto e sujeito, estancaria uma interação propriamente dita.

É um tal nexo intersubjetivo que complementa, para a auto-constituição do sujeito, as insuficiências de uma contraposição prático-teórica do mesmo ao mundo. Em que medida a compreensão do mundo seja, graças à irredutibilidade da gênese intersubjetiva da autoconsciência à perspectiva monológica, social, cultural ou previamente partilhada, não se esclarece na argumentação. Fichte pretende que as condições da consciência-de-si individual sejam satisfeitas pelos pressupostos da compreensão da interpelação. A interação se pauta pelo apelo ao entendimento < Verstand $>$, o que pressupõe, por sua vez, um "ser capaz de conceitos" < ein der Begriffe fähiges Wesen>. "Somente a interação livre através de conceitos e segundo os mesmos, somente o fornecimento e a recepção de conhecimentos < Geben und Empfangen von Erkenntnissen>, é o caráter peculiar da humanidade, pelo qual somente se corrobora toda

doispontos, Curitiba, São Carlos, vol. 4, n. 1, p. 63-106, abril, 2007 
pessoa inequivocamente como ser humano." (FICHTE, 1971, 40) A partir desta caracterização quase-lingüística da interpelação e das condições de sua compreensibilidade como ensejo à expressão da liberdade, fica claro que está implícito, na compreensão da mesma, não somente um saber do solicitante como ser racional, mas também o próprio sujeito interpelado "tem de poder se certificar de que seu parceiro de interação vincula, com seu ato de fala, a suposição de encontrar diante de si, no endereçado, um ser racional, que é capaz de perspiciência $<$ Einsicht $>$ acerca dos fundamentos e, portanto, de agir por liberdade." (HONNETH, 2001, 74) Isto levanta a delicada questão acerca de em que medida a Aufforderung pressupõe, inscrita na expectativa de uma atitude racional por parte do interpelado, o reconhecimento do mesmo, ainda que não como pessoa de direito, mas, ao menos, como sujeito capaz de uma reação autônoma em termos de declinação ou aceitação da solicitação.

Entretanto, é seu programa de distinção fundamental entre direito e moral (KERSTING, 2001) - e, portanto, entre a intersubjetividade indiferente da intangibilidade mútua das esferas de ação e a possibilidade de uma relação intersubjetiva positiva entre os indivíduos - que faz com que Fichte evite, apesar da expectativa do interpelador por uma resposta não coagida e seu potencial interesse em iniciar uma cooperação, sobrecarregar "deontologicamente" a interpelação. $\mathrm{Na}$ medida em que a condição da autoconsciência reside nos pressupostos de compreensão do tratamento racional, esta acepção é o minimum necessário à revogação da aporia de uma explicação da autoconsciência pelo modelo do sujeito auto-referente. Por conseguinte, a postura potencialmente participativa na formação recíproca das vontades é, antes, neutralizada na forma de uma Behandlung (FICHTE, 1971, 47), ainda que Fichte identifique a interpelação explicitamente com a socialização dos indivíduos pela educação: a partir da própria argumentação de Fichte, torna-se claro que esta socialização é compreendida também em um sentido individualizante, ou seja, em um sentido que pressupõe uma relação positiva e participativa entre as vontades, e não simplesmente à maneira da socialização indiferente do direito. "A interpelação à livre auto-atividade < freie Selbsttätigkeit $>$ é aquilo a que se chama educação $<$ Erziehung $>$. Todos os indivíduos precisam ser educados para se tornarem seres humanos." (FICHTE, 2001, 47) No

doispontos, Curitiba, São Carlos, vol. 4, n. 1, p. 63-106, abril, 2007 
entanto, é dificil ver, especialmente em face do nexo individualizante inerente a uma socialização pela educação, como esta forma específica de intersubjetividade, a qual Fichte compreende como condição primordial da consciência-de-si individual, não engendraria imediatamente uma forma positiva e participativa de relação intersubjetiva. Mesmo que se reduza, como faz Honneth - não totalmente sem respaldo de Fichte -, a Aufforderung ao nível de um simples "dirigir-se ao outro com diligência", não fica claro como, a partir do interpelador, a solicitação que se abstém de utilizar o outro como simples objeto, que lhe concede o "privilégio" de uma reação ou expressão baseada na não-coerção e que se aproxima do exercício de uma socialização necessariamente individualizante, não possui conotações inerentemente "éticas" e "inclusivas", dotadas de um potencial intersubjetivo que não se reduz a um "confronto" indiferente entre pessoas de direito, na medida em que a este confronto subjaz a intenção individualista generalizada de uma exclusão recíproca na formação do outro enquanto individualidade coesa. Motivado a anular a coerção sobre o "educando", o "educador" tem de ter, caso não lhe interesse, sob a pressuposição de que age formativamente, apenas a persecução desobstruída de seus fins, não somente uma representação jurídico-moral do valor intrínseco da humanidade como fim em si, mas a intenção e os meios previamente articulados de participar ativamente na formação do outro como subjetividade plenamente acabada.

Uma conotação moral da interpelação - e, de maneira mais profunda, sua consideração como matriz intersubjetiva de relações interpessoais tanto excludentes quanto inclusivas - vai além da abordagem de Fichte e mesmo dos objetivos pretendidos por ele com a introdução do conceito ${ }^{4}$; pois o interpelado não está aqui obrigado a reagir ético-moralmente, mas apenas instado a reagir com racionalidade e liberdade. Mas se, a partir da interpelação, uma possível abertura para a reconstrução de uma moral universalista da humanidade como fim em si e como nexo fundacional de formas "participativas" de uma "socialização individualizante" pode ser encontrada em germe, ela não estaria na perspectiva unilateral do interpelado, mas na conduta não coerciva e socialmente "pré-articulada" do interpelador. As conseqüências normativas, bem como a redução das potencialidades éticas da interpelação como modelo geral de uma socialização anterior à mútua exclusão das pessoas de direito, são delineadas

doispontos, Curitiba, São Carlos, vol. 4, n. 1, p. 63-106, abril, 2007 
pela transformação da constituição unilateral da consciência-de-si do interpelado no modelo bilateral do reconhecimento recíproco, relação originária que subjaz a toda relação intersubjetiva arbitrária e que revela, como atrelada a uma resposta racionalmente formulada à abordagem, a obrigação de atribuir ao outro uma esfera de liberdade que foi concedida na solicitação (HONNETH, 2001, 79). Porém, justamente porque se trata, com a interpelação, de um nexo intersubjetivo que, para ser compreendido, "tem de ser de tal forma que ambos se constituam como partes integrantes de um acontecimento como todo <einer ganzen Begebenheit>" - pois só "assim algo é postulado como condição da consciênciade-si de um ser racional" (FICHTE, 1971, 34/35) -, ela tem de ser também considerada em seu potencial ético e inclusivo.

O terceiro "princípio doutrinário", desenvolvido no $\$ 4$, tem a função de explicitar a relação intersubjetiva deduzida no segundo "princípio doutrinário" como sendo o reconhecimento recíproco de dois seres racionais enquanto sujeitos de direitos que eles atribuem simetricamente um ao outro. Com efeito, o objetivo é mostrar que a relação intersubjetiva constitutiva para a certificação da subjetividade é a própria relação jurídica. Este nexo, a intersubjetividade como relação de direito, representa o coroamento de toda a argumentação da primeira "parte principal" da obra. Deduzindo a relação de direito como condição da subjetividade, a primeira parte da obra mostra o conceito de direito como correspondente a uma ação necessária do eu, sem a qual não se faria valer como liberdade refletida sobre si. Como o âmbito de sua dedução é a explicação da autoconstituição do indivíduo concreto ${ }^{5}$, o direito está vinculado à tentativa de conferir validade à finitude essencial da subjetividade prática, para a qual o efetivo e o possível não concordam absolutamente.

O vínculo pretendido por Fichte entre o Naturrecht e a Grundlage de 1794 responde pela extensão do titulo - nach den Prinzipien der Wissenschaftslehre - e orienta a investigação aos atributos racionais do sujeito finito (SIEP, 1991a, 1991b) e não aos pressupostos transcendentais sob os quais o eu, pensado como absoluto, retorna a si mesmo. O eu absoluto se põe a si mesmo pura e simplesmente $<$ schlechthin $>$, sem qualquer relação de dependência a outra coisa além de si mesmo. O eu puro, enquanto unidade indiferenciada de sujeito e objeto, condição de toda a separação entre os mesmos e de toda consciência, é, segundo Fichte, pura

doispontos, Curitiba, São Carlos, vol. 4, n. 1, p. 63-106, abril, 2007 
atividade. Já o eu finito é tal que tem, como condição de sua autoposição, a atividade que reflete sobre algo limitado, retornando a si mesma. A autoconsciência do eu finito envolve a certificação reflexiva de si em uma relação a outras coisas além de si mesmo. A atividade do sujeito finito tem necessariamente de ser uma in sich zurückkehrende Tätigkeit, que é, neste sentido, não-absoluta e limitada <begrenzt>, uma vez que ela encontra, em sua auto-compreensão, em sua auto-constituição como subjetividade consciente-de-si, elementos de si mesma que não tem como reduzir aos produtos de sua própria atividade.

A "transformação" da Wissenschaftslehre em reconstrução da consciência individual, em "ciência real", corresponde, no Direito Natural, à exigência de partir, para chegar à compreensão da necessidade racional da vida em comunidade, do indivíduo enquanto um ser racional entre outros; de maneira que, nesta obra, desde o princípio, o sujeito, cuja consciência-de-si deve ser explicada por meio de uma dedução transcendental, é um sujeito cuja identidade se forja como consciência da própria "limitação". Tal mudança de enfoque é compreendida por Fichte como uma derivação das ciências concretas a partir da filosofia primeira, fundada na "reconstituição", pelo eu absoluto, das condições de sua autoconsciência originária.

Portanto, sob o ponto de vista do indivíduo, o $\$ 4$ reconstitui o nexo segundo o qual o ser humano somente se encontra constituído como subjetividade sendo membro de uma comunidade jurídica, fundada na limitação recíproca das liberdades. $\mathrm{O}$ argumento de Fichte desemboca na tentativa, anunciada no corolário do $\$ 6$, de prover a moral kantiana com um aparato conceitual capaz de mostrar sua aplicabilidade $<$ Anwendbarkeit $>$. Uma ética que ergue uma pretensão normativa fundada na noção de respeito recíproco universal e da relação positiva à vontade do outro tem, na constituição intersubjetiva do direito, sua apresentação sensível e se revela, desta forma, para Fichte, como a contrapartida da teoria da constituição da consciência individual: "a conditio juris é a própria conditio humana" (RENAUT, 2001, 83). É no sentido deste vínculo entre a apresentação sensível e jurídica de uma ética de pretensão intersubjetiva com a "constituição" da autoconsciência que se pode atribuir à teoria fichteana do reconhecimento a tentativa de reconstrução genética da intersubjetividade jurídico-moral. Entretanto, se a subjetivi- 
dade "plenamente formada" vem atrelada, para Fichte, pela "mútua exclusão" das individualidades na forma de atribuição recíproca de esferas limitadas de ação, isto já representa uma limitação do potencial socializador de uma individualização que se desenvolve segundo o modelo de uma educação formativa.

"O sujeito agora se pôs enquanto um tal que contém em si mesmo o último fundamento de algo que está nele (esta foi a condição da egoidade, da racionalidade em geral); mas ele pôs, da mesma forma, um ser fora de si como último fundamento disso que nele aparece <als den letzten Grund dieses in ihm Vorkommenden >." (FICHTE, 1971, 41) Assim, por um lado, a consciência somente pode se certificar de si mesma pela admissão de outras consciências; e, por outro lado, a postura não coercitiva, que é condição para a compreensão da solicitação e para a auto-certificação, só é possível como limitação da esfera de liberdade, de maneira que o sujeito só pode chegar à consciência-de-si ao considerar a si mesmo como sujeito ao vínculo jurídico. "O ser racional finito não pode admitir outros seres racionais exteriormente a si, sem pôr-se como estando em uma determinada relação com eles, a qual se denomina relação de direito $<$ Rechtsverhältnis>." (FICHTE, 1971, 41)

Deste modo, a questão da reconstrução da autoconsciência individual se tornou o problema da possibilidade da liberdade intersubjetiva. Portanto, em primeiro lugar, é preciso que se contraponham dois seres racionais, que não poderão, de acordo com o pressuposto, abandonar sua pretensão à liberdade, pelo que não se tornam consciências-de-si (FICHTE, 1971, 41). Assim, em vista do processo dedutivo próprio ao primeiro Hauptstück, trata-se de encontrar a condição de uma simples contraposição e conseqüente "separação" dos seres racionais em uma "intersubjetividade indiferente", a qual representa, por assim dizer, a redução do potencial de uma socialização baseada na intersubjetividade formativa ${ }^{6}$. Para Fichte, somente sob a pressuposição da contraposição e da necessária auto-atribuição de uma esfera de liberdade, o ser racional "pode pôr a si mesmo enquanto único fundamento de algo, separar-se totalmente do ser livre fora dele e atribuir sua eficácia somente a si." (FICHTE, 1971, III, 41/42)

A condição para a separação, isto é, para a auto-posição de um ser racional como contraposto a um outro ser racional, é que a última determinação de sua liberdade esteja sob seu controle. A interpelação forneceu 
a condição para que surgisse o indivíduo enquanto sujeito prático capaz de exteriorizar sua liberdade: uma socialização que tem em sua base a relação intersubjetiva em seu potencial "indeterminado", isto é, representa, em geral, o ponto de vista de uma atitude performativa que se abstém da coerção sobre o outro, a qual constitui, por isso mesmo, a possibilidade de formas inclusivas, cooperativas e não indiferentes de intersubjetividade. No entanto, de acordo com o movimento da racionalidade finita, demonstrado na Wissenschaftslehre de 1794, "eu oponho, no eu, ao eu divisível, um não-eu divisível” (FICHTE, 1971, I, 110), "um princípio teórico formal, o qual foi, no seu devido lugar, rigorosamente demonstrado, e que, com sorte, pareça convincente ao intelecto humano sadio mesmo sem prova" (FICHTE, 1971, III, 42); de maneira que a autoposição do indivíduo, graças ao fundamento último de determinação de sua eficácia, deixado e instado pelo ser racional que o interpelara e o trouxera à consciência-de-si, implica que estes, estando contrapostos, tenham sido postos em relação de comparação um com o outro. "Não pode ser contraposto, se, no mesmo momento indiviso da reflexão, os contrapostos não forem também equiparados (gleichgesetzt), relacionados um ao outro e comparados um com o outro." (FICHTE, 1971, III, 42)

O chegar-à-consciência-de-si do ser racional pelo modelo da interpelação tem como condição necessária, segundo a intenção de uma redução jurídica dos nexos societários intersubjetivos, a contraposição de dois indivíduos, a qual fora condicionada pela atitude do interpelador em optar pela possibilidade de uma resposta não coagida. Para a dedução do direito apenas a não-coercibilidade, o minimum da situação de interpelação, a ação indiferente e vinculada apenas à determinação universal do ser-pessoa, faz-se necessária. Isto revela um potencial ético-inclusivo, implícito na noção de interpelação, na medida em que "ambos estão necessariamente unificados ... conhecem <erkennen $>$ um ao outro em seu interior" (FICHTE, 1971, 85/86). Entretanto, estritamente jurídica permanece a intersubjetividade, na medida em que "a liberdade não possui nisto o menor espaço para hesitação $<$ Spielraum $>$... surge um conhecimento comunitário, e nada além disso. Ambos conhecem <erken$n e n>$ um ao outro em seu interior, mas estão isolados, como antes." (FICHTE, 1971, 85/86) Neste sentido, de acordo com a linha adotada por Fichte, a dedução do direito como "conceito originário da razão

doispontos, Curitiba, São Carlos, vol. 4, n. 1, p. 63-106, abril, 2007 
pura" (FICHTE, 1971, 7) tem como contrapartida uma "redução" jurídica da intersubjetividade, primeiramente deduzida como educação, tornando-a o ambiente propriamente contratualista da defrontação de indivíduos plenamente individualizados enquanto pessoas. A reciprocidade na auto-limitação da liberdade, o direito enquanto "comunidade das consciências" que se reconhecem mutuamente e a individualização dos seres racionais se condicionam reciprocamente, de maneira que uma individualização segura e indiferente de todos como pessoas depende da continuidade da reciprocidade do reconhecimento. Entretanto, pode-se perceber como, a partir de Fichte, pode ser levantada a questão acerca da simbiose entre esta individualização indiferente e formas participativas de socialização que poderiam ser pensadas sob o título de educação.

\section{Aglutinação do nexo formativo ao amor no jovem Hegel}

As versões "fenomenológicas" do "movimento do reconhecer" comprovam como determinados aspectos da filosofia prática de Fichte permanecem determinantes para o Hegel maduro. Na Enciclopédia, apesar de compreender o primeiro grau da autoconsciência também como desejo, o afastamento em relação à emergência do mesmo a partir da vida torna ainda mais acentuada a crítica a Fichte, o que se faz notar na ênfase ao caráter “excludente” e "unilateral” (HEGEL, 1995, \$426 adendo) da subjetividade singular do desejo, a ser suspenso na autoconsciência universal ${ }^{7}$. Neste contexto, Hegel trata o desejo como re-interpretação do princípio da identidade indiferenciada, que fornece o ponto de partida para o "jus-racionalismo" da filosofia transcendental, como unidade subjetiva solipsista, a qual precisa ser superada pela inclusão do outro, a fim de permitir a elevação da suposição subjetiva da certeza de si à verdade da identidade concreta, que mantém conservada a diferença real, de que depende a possibilidade da identidade da consciência-de-si, da liberdade e da razão (FALKE, 1996, 151).

Assim, Hegel começa com a identidade abstrata a si com a finalidade de ultrapassá-la e mostrar a sua verdade: a consciência-de-si universal, a razão ou o conceito de espírito (HEGEL, 1995, \$417). Na Enciclopédia, a ênfase na deficiente auto-referencialidade absoluta do desejo encontra 
seu sentido geral no argumento que pretende incumbir a teoria da eticidade de expor as condições da efetivação de uma intersubjetividade plenamente recíproca, cuja base estrutural se mostra, ainda no "Espírito Subjetivo", como condicionada pelo descentramento do solipsismo do desejo (WILLIAMS, 1997). O desejo é egoísta ou referido somente a si e não possui ainda a capacidade de reconhecer o outro como si, nem a si mesmo no outro; e por isso encontra alter como algo a manipular, e não como co-participante na formação de sua própria identidade, de seu concreto saber de si.

"A relação do desejo ao objeto é ainda totalmente a relação do destruir egoísta, não a do formar. Enquanto a consciência-de-si se refere ao objeto como atividade formativa, esse objeto recebe somente a forma do subjetivo, que nele adquire uma subsistência: mas é conservada segundo o seu conteúdo. Ao contrário, pela satisfação da consciênciade-si aprisionada no desejo, já que ela ainda não possui a força de agüentar o Outro como algo independente, a autonomia do objeto é destruída; de modo que a forma do subjetivo não alcança nele subsistência alguma." (HEGEL, 1995, \$428, adendo)

No presente contexto, pode parecer excessiva uma leitura "intersubjetivista" do "formar", o qual parece, principalmente em vista do teor "destrutivo" do egoísmo desejante, conectar-se com o "refreamento" do desejo no trabalho. Entretanto, na medida em que, para o desejo, tudo é objeto em sentido rigoroso, e mesmo outros "sujeitos" são vistos como objetos, algum teor "intersubjetivista" pode ser depreendido da oposição entre a "destruição da autonomia do objeto" e a "formação de sua subjetividade".

Portanto, não é difícil ver, no estágio imediato do princípio do idealismo, a vacuidade simples e exclusão de toda diferença, o sujeito-objeto subjetivo, o qual Hegel já criticara, desde Frankfurt, como elemento deflagrador de dominação sobre a natureza exterior e interior. A inserção desta crítica em uma re-interpretação do argumento contratualista conduz Hegel a uma mediação entre o eu e o outro imanente à singularidade da consciência natural e não à pressuposição da universalidade do estado ou da lei moral (FALKE, 1996, 144).

Entretanto, o cenário da tematização do problema da intersubjetividade no jovem Hegel é bastante peculiar, principalmente porque não há, 
nesta fase (Frankfurt e Jena) a desvinculação entre reconhecimento e "vida ética". Se é possível, nos escritos de juventude de Hegel, depreender-se o embate entre dois paradigmas de intersubjetividade (LIMA, 2006, 69 e ss.), isto não se deve, certamente, a uma assimilação de Fichte, mas ao registro de questões que conduzem Hegel, a partir de Jena, à filosofia especulativa. O embate entre concepções de intersubjetividade é ocasionado principalmente pela perspectiva histórico-espiritual a partir da qual Hegel contempla o desenvolvimento do "espírito" grego e cristão (LUKÀCS, 1986), filtrada também pela enorme influência exercida pelo ideário da Vereinigungsphilosophie (BONDELI, 1997). Entretanto, a influência de Fichte sobre Hegel vai se tornar decisiva justamente para a elaboração de uma conexão entre a intersubjetividade inclusiva do amor e a intersubjetividade excludente do direito. É na articulação entre os pólos do amor e da luta (SIEP, 1979, 37), os quais fornecem a amplitude normativa da concepção hegeliana de reconhecimento, que os nexos individualizantes ínsitos na socialização típica da formação pela educação ganham em importância.

$\mathrm{O}$ atrito entre formas de intersubjetividade tem seu ponto de partida ainda no período de Tübingen, quando Hegel é levado a relacionar o amor à moral deontológica, no contexto da investigação acerca das condições de possibilidade de uma Volksreligion moderna, a qual, seguindo o modelo grego de uma religião viva e capaz de falar à fantasia do povo, pudesse fazer frente tanto ao "positivo" quanto à sua negação pelo esclarecimento. Neste contexto, o amor é compreendido como elemento constituinte desta Volksreligion, respondendo pela adesão subjetiva à mesma. Hegel atribui ao amor entre os seres humanos o papel de princípio fundamental do "caráter empírico", mas o compreende como algo que é moral em si mesmo, na medida em que eleva o poder do direcionamento da natureza impulsiva pela validade prática da relação intersubjetiva racionalmente motivada.

"O princípio fundamental do caráter empírico é amor, o qual tem algo de análogo com a razão, na medida em que o amor se encontra a si mesmo em outros seres humanos, ou antes, esquecendo-se de si mesmo, põe-se para fora de sua existência, como que vive em outro, sente e é ativo - tal como a razão, enquanto princípio de leis universalmente válidas, reconhece-se a si mesma novamente em todo

doispontos, Curitiba, São Carlos, vol. 4, n. 1, p. 63-106, abril, 2007 
78

ser racional enquanto concidadã de um mundo inteligível. O caráter empírico é, na verdade, afetado por prazer e desprazer, mas amor, se ele já é um princípio patológico do agir, é altruísta <uneigennützig>."

(HEGEL, 1970, I, 30)

Esta racionalidade intrínseca ao amor, revelada curiosamente no aspecto intersubjetivo desta relação, permite que ele seja este composto, uma inclinação cujo caráter patológico não a torna menos digna, nem nada retira de sua grandeza (HEGEL, 1970, I, 362). Já em Tübingen, Hegel vai além da distinção kantiana entre o "amor a Deus" e seu teor práticomoral, por um lado; e o "amor intersubjetivo" e seu caráter patológico", por outro. Os paradigmas cristãos do "amor a Deus" e do "amor ao próximo" são considerados por Hegel como enunciações paralelas de um mesmo "princípio": a prática dos deveres em geral ou para com o outro por satisfação <gerne tun>. Por isso - e aqui se encontra a raiz das reflexões de Hegel sobre o amor em Frankfurt -, o "amor intersubjetivo", mesmo sensível e próximo ao prazer e à satisfação como qualquer inclinação, tem, para Hegel, um papel importante na promoção da prática moral, na medida em que seres humanos que se amam estão atentos ao cumprimento dos deveres para com outro não simplesmente "por dever" ou por pura observância da lei universal de respeitar os outros como pessoas, mas sobretudo porque o fazem "com satisfação", como parte da realização de sua própria identidade pessoal, na medida em que esta se compreende em sua plenitude somente naquela relação de amor, de estimar o outro e ser por ele estimado. No amor, segundo Hegel, o altruísmo universalmente exigido pela razão moral não é coerção do caráter inteligível sobre o empírico, não é dominação e controle da razão sobre o egoísmo inato, mas cumprimento espontâneo do dever, unificação da satisfação subjetiva mais íntima com o comportamento objetivamente válido de respeito ao ser humano como fim em si. Este alinhamento entre amor, altruísmo e a racionalidade da moral impede que o amor, como inclinação, seja ligado à "racionalidade pragmática" do entendimento, vinculado à satisfação do "amor de si” e do egoísmo.

A compreensão da relação entre o amor e formas "excludentes" de intersubjetividade se aprofunda, sobretudo, no período de Frankfurt. Primeiramente, nos Entwürfe über Religion und Liebe, texto composto de 
três fragmentos, escrito no primeiro ano de estadia em Frankfurt em um linguajar notadamente fichteano, que revela decerto o impacto do estudo da Grundlage de Fichte no verão de 1795 (ROSENKRANZ, 1972), mas também a profunda influência de Hölderlin (JAMME, 1988, 1990) ${ }^{9}$. Segundo o trecho “Amor e Religião", a religião verdadeira não está nem em um objeto fora do sujeito, o que suscitaria positividade e autoridade, nem em um objeto que está somente no sujeito, o que perverteria o sentido comunitário de uma religião plena. "O ideal nós não podemos pôr fora de nós, senão seria um objeto - [mas também] não somente em nós, senão não seria nenhum ideal.” (HEGEL, 1970, I, 244) Neste paradoxo, pode-se perceber todo o significado comunitário da concepção hegeliana da unificação <Vereinigung > . Hegel pretende que a solução para este dilema esteja numa religião que é "um com o amor" < die Religion ist eins mit der Liebe> (HEGEL, 1970, I, 244).

A religião tem de incorporar a validade interpessoal e intersubjetiva autêntica do amor, para além da dicotomia sujeito e objeto. A religião verdadeira está no sentimento de diversos sujeitos de serem um no amor. O divino, o místico e religioso estão nesta intersubjetividade, nesta comunidade de seres na qual eles perdem o caráter solipsista do indivíduo solitário e vêem-se no outro como objetos, isto é, vêem no outro a si mesmos. O caráter "divino" - e, posteriormente, especulativo, inacessível ao entendimento (HEGEL, 1995, \426 adendo) - desta intersubjetividade, desta "socialização positiva" -, posto que não concerne a seres humanos simplesmente como indivíduos apartados uns dos outros, mas como indivíduos inteiros, estimados, apreciados e plenamente individualizados pela própria "socialização" -, jamais abandonará a filosofia social de Hegel. "A religião é um com o amor. O ser amado < der Geliebte> não nos é contraposto, ele é um com nossa essência. Nós vemos somente a nós nele; e, contudo, em seguida, novamente ele não é nós - um milagre que não somos capazes de compreender.” (HEGEL, 1970, I, 244)

O quão vigorosa é a tematização da intersubjetividade no jovem Hegel torna-se claro pelo fato de que o fragmento welchem Zwecke denn ..., considera não somente o "göttliche Liebe", mas sobretudo e explicitamente o amor conjugal, sexual e relações amorosas tangenciadas por relações interpessoais mediadas pela relação às coisas. A este "amor pelo que é morto" Hegel contrapõe o amor verdadeiro, o qual diz respeito aos

doispontos, Curitiba, São Carlos, vol. 4, n. 1, p. 63-106, abril, 2007 
"seres vivos" e nada tem em comum com a dominação e controle do mundo objetivo pela associação de indivíduos autônomos. O que se torna problemático para a força unificadora do "amor intersubjetivo" é que os seres humanos querem viver também como indivíduos autônomos e têm, por isso, de viver em relações de outra natureza e que são reguladas por normas morais e jurídicas. "Os que amam estão em ligação com muita coisa morta: a cada qual pertencem muitas coisas, isto é, está em relação com contrapostos que, também para aquele que se relaciona, são ainda contrapostos, objetos. E assim eles são ainda capazes de uma múltipla contraposição na múltipla aquisição e posse de propriedade e direitos." (HEGEL, 1970, I, 249) Por outro lado, o amor verdadeiro "é um recíproco receber e dar" (HEGEL, 1970, I, 247): “aquele que recebe não se torna por meio disso mais rico que o outro: na verdade, ele enriquece, mas tanto quanto o outro. Igualmente, aquele que dá não se torna mais pobre: ao dar ao outro, ele faz aumentar na mesma quantidade seus tesouros" (HEGEL, 1970, I, 247). Ele se rege pela lógica de uma doação recíproca e pelo "acúmulo" de "riqueza da vida", enquanto a relação intersubjetiva em vista do que é morto se baseia na matéria, segue a lógica da troca e se rege pela atribuição recíproca de direitos de propriedade:"o mais pobre hesita em tomar [algo] ao mais rico, a se pôr numa mesma posse com ele, porque este mesmo praticou uma ação do contrapor, pôs-se para fora do círculo do amor. Mas a este temor, que sua propriedade desperta, o possuidor se antecipa ao conferir a ele seu direito de propriedade, que lhe cabe contra qualquer outra pessoa, que se suprime em face daquele que ama ..." (HEGEL, 1970, I, 249).

Para além dos significados ontológicos e mesmo especulativos da enunciação da unificação por amor, Hegel contrapõe, pela primeira vez, sua concepção de uma "intersubjetividade positiva", em que se deixa antecipar a afirmação recíproca de identidades e origem comum de consciência universal e consciência individual, a uma "intersubjetividade negativa", que se pauta pela solidificação da autonomia individual em relações sociais atomísticas e que resulta tão-somente numa associação comum em vista de fins relativos. O texto de Hegel sugere que o conflito entre "amor verdadeiro" e "amor em vista do que é morto" como um conflito entre a relação ética (nos Entwürfe compreendida preponderantemente como relação conjugal, mas já em Geist des Christentums consid- 
erada num viés mais amplo como fraternidade ou amizade) e a relação contratual entre proprietários, ambas relações intersubjetivas que se diferenciam justamente pela irredutibilidade absoluta do indivíduo, característica fundamental de um mundo burguês baseado em relações de direito privado. Este conflito, compreendido como conflito entre formas paradigmáticas de intersubjetividade, antecipa magistralmente toda a crítica hegeliana, desde o Naturrechtaufsatz até as Grundlinien, às tentativas jus-naturalista e jus-racionalista de se compreender relações éticas pelo paradigma das relações jurídico-privadas ou contratuais, em particular, o casamento e o próprio Estado (HEGEL, 2006, \$75).

Esta limitação do poder unificante do amor pelas formas jurídicas de relação intersubjetiva é a tônica dos escritos de Frankfurt e está na raiz da intuição hegeliana, alcançada finalmente em Geist des Christentums, de que, em vista do desenvolvimento da modernidade política e seu reconhecimento do "direito da particularidade", da "liberdade irredutível da pessoa" - e, conseqüentemente, da legitimidade de um ethos universal do egoísmo -, a fraternidade e a solidariedade, preconizada pelas comunidades cristãs primitivas, não possuem um poder sócio-integrador em condições socialmente ampliadas. A tensão, inerente à vida familiar, entre os indivíduos como membros deste todo ético (HEGEL, 2006, \$158) e a persistência dos indivíduos apartados enquanto pessoas de direito, os quais são "formados" como resultado da educação no seio da própria família (HEGEL, 2006, \$175 e \$177), é assimilada justamente à gênese conceitual deste produto singular da formação da modernidade política: a sociedade civil enquanto esfera do esfacelamento da eticidade imediata da família, o âmbito da diferença e da mediação, onde, entretanto, se efetiva, no bojo da atividade econômica e produtiva emancipada, a autonomia da particularidade pela mediação social e jurídica da persecução dos interesses privados.

A assimilação positiva de Fichte em Jena tem suas raízes no fato de que a "crise de Frankfurt" se revela, no registro da filosofia social, como impossibilidade de articular concretamente as formas de intersubjetividade. Justamente no contexto desta articulação Hegel será levado a uma melhor apreciação da tese fichteana dos nexos formativos que possibilitam a relação de direito. Os fragmentos que compõem Geist des Christentums und sein Schicksal convergem para um resultado aporético, o qual representa, 
em geral, a derrocada da expectativa de Hegel quanto a uma integração social, em condições sociais "complexas" que se baseiam na garantia dos direitos individuais e salvaguarda das relações jurídico-privadas, através de uma Volksreligion vinculada ao amor." O destino da propriedade se tornou poderoso demais para nós, mais ainda do que reflexões sobre isso seriam suportáveis, do que sua separação de nós nos seria pensável." (HEGEL, 1970, I, 333) A aporia se estabelece pela mútua exclusão entre a forma genuinamente espiritual e originária de relação comunitária, definida pelo âmbito de solidariedade, confiança, fraternidade e perdão do amor, por um lado; e as relações sociais que supõem formação das individualidades, seu destacamento da unicidade vital das consciências e sua "confrontação" no horizonte da afirmação excludente da autoconsciência individual, e que são compreendidas por Hegel em geral como "relações de direito" $<$ Rechtsverhältnisse $>$, por outro lado. "Assim, amor e luta não são vistos ainda, em Espírito do Cristianismo, como dois momentos de um processo de interação no qual a autoconsciência se forma por separação e unificação. A separação que o amor tenciona ultrapassar pode ter diferentes causas: não somente o conflito por direitos - que pressupõe uma determinada situação histórica -, mas ainda também a reflexão, assim como, de maneira geral, o 'desenvolvimento' e formação $<$ Ausbildung $>$ da individualidade.” (SIEP, 1979, 49) O processo de individualização, enquanto processo de mútua exclusão de individualidades, não somente parece não fazer parte da "unicidade da consciência" dos indivíduos, como ainda corresponde à ameaça de seu colapso.

Em Espirito do Cristianismo, a "individualização" conduz, enquanto destacamento dos seres humanos da unidade vital e que resulta na sua contraposição enquanto pessoas privadas, a um ambiente que impossibilita o retorno à harmonia intersubjetiva: nesta obra, Hegel mostra que o retorno à unidade vital pressupõe a "revogação" do ponto de vista jurídico-moral dos direitos individuais. Em sintonia com o apelo de Jesus ao despojamento das riquezas e à renúncia das posses, Hegel compreende o ambiente criado pelo destacamento das individualidades num registro que salienta o aparecimento das pessoas privadas, dotadas de direito de propriedade e de proteção à pessoa ${ }^{10}$ : "deve-se compreender que a / posse de riqueza - com todos os direitos, assim como com todas as preocupações que se conectam com isso - traz determinidades para o ser

doispontos, Curitiba, São Carlos, vol. 4, n. 1, p. 63-106, abril, 2007 
humano cujos limites impõem às virtudes suas barreiras, indicam-lhes suas condições e dependências, em cujos limites há bem espaço para deveres e virtudes, as quais, contudo, não permitem nenhum todo, nenhuma vida completa, porque é ligada a objetos, têm as condições de si mesmo fora de si." (HEGEL, 1970, I, 333/334)

Com efeito, afora demais aspectos ligados à noção de Bildung da individualidade, a formação e institucionalização da pessoa privada e das relações jurídico-privadas formam um núcleo importante do processo de destacamento que Hegel tem em mente. Para Hegel, tal institucionalização da pessoa privada traz consigo um arcabouço sócio-regulador que forma um "tecido de legalidades" < Gewebe der Gesetzlichkeiten> (HEGEL, 1970, I, 401), uma multiplicidade de direitos que tornam obsoletas as virtudes genuinamente intersubjetivas enquanto "modificações do amor", e privilegiam um agir "ético" ou "virtuoso" baseado na “exclusão", entendida aqui no horizonte do processo de formação de individualidades mutuamente excludentes.

"A riqueza revela, portanto, sua contraposição ao amor, à totalidade, através disso: que ela é um direito e é conceituada numa multiplicidade de direitos, através do que, em parte sua virtude, que se relaciona imediatamente a ela, a retidão; em parte as outras virtudes, possíveis nos limites de seu círculo, são necessariamente ligadas com exclusão, e cada ato de virtude é em si um contraposto.” (HEGEL, 1970, I, 334)

Para Hegel, a relação intersubjetiva sob a égide do paradigma da justiça é uma relação mutuamente excludente entre os indivíduos cujo fim é estabelecer o ponto de vista reciprocamente reconhecido da igualdade do direito de ambos. Entretanto, a própria posição de Hegel com respeito ao amor é dificil de se apreender em seu verdadeiro teor, o que em muito se deve à sua expectativa quanto ao poder de integração social do amor como cerne da Volksreligion. Por um lado, diz Hegel, "no amor o ser humano se reencontrou a si mesmo no outro. Porque ele é uma unificação da vida, pressupunha a separação, um desenvolvimento, uma multilateralidade formada da mesma." (HEGEL, 1970, I, 394/395) Entretanto, a este reconhecimento de que o amor pressupõe, enquanto unificação da vida, a separação e a formação <Bildung $>$ dos elementos cindidos, se contrapõe a percepção mais ou menos clara de que, sob determinadas

doispontos, Curitiba, São Carlos, vol. 4, n. 1, p. 63-106, abril, 2007 
circunstâncias sociais, o amor não é capaz de nadificar todas as cisões operadas no seio vital pela individualização, mas se torna excludente em relação a determinadas formas de vida: "e em quanto mais figuras a vida é viva, em tanto mais pontos ela pode se unificar e sentir, tanto mais interior é o amor. Quanto mais ampliadas em multiplicidade são as relações e os sentimentos dos que se amam, quanto mais interiormente o amor se concentra, tanto mais excludente ele é, tanto mais indiferente [ele é] a outras formas de vida."(HEGEL, 1970, I, 394/395)

Para Hegel, a ampliação do alcance da unificação amorosa tem a tendência de não abarcar o todo da vida social, mas passa a se comportar de maneira excludente com relação a uma individualização socialmente sistemática. Indiferente a um emaranhado de relações que cindem a unidade vital pelo destacamento das individualidades, parece restar ao amor somente a "efetivação localizada" no interior de círculos restritos de indivíduos numa completa sintonia de atitudes, indivíduos, poder-seia dizer, que participam do mesmo ethos. "Através da ampliação do amor a uma comunidade inteira, resulta no caráter do mesmo que ela não é uma unificação viva das individualidades, mas antes que a fruição do mesmo se limita à consciência recíproca de que elas se amam." (HEGEL, 1970, I, 405)

A questão não é para Hegel nada trivial: sobre a possibilidade de uma integração socialmente abrangente pelo princípio do amor se baseia sua expectativa quanto à restauração da beleza de uma "religião do povo". "A amizade das almas enquanto essência, enquanto espírito pronunciado para a reflexão, é o espírito divino, Deus, o qual governa a comunidade. Há uma idéia mais bela do que um povo de seres humanos que são relacionados uns aos outros pelo amor? uma mais arrebatadora do que pertencer a um todo que, enquanto todo, uno, é o espírito de Deus, cujos filhos são os singulares?” (HEGEL, 1970, I, 394) Diante desta bela idéia de um povo de Deus, Hegel constata, entretanto, que a integração social abrangente tem que se basear em outros elementos, os quais concebe já em certa sintonia com o que se tornará, posteriormente, o "sistema de carências" (HEGEL, 1970, I, 395).

A unificação de muitos está inextricavelmente ligada, para Hegel, à postura comunitária para a resolução do problema comum da necessidade, o que unicamente pode render, em circunstâncias sociais 
abrangentes, um télos objetivo para as ações sociais em comum. $\mathrm{Na}$ medida em que, nesta "unificação", o trabalho individual orientado pelo télos comum, bem como as relações jurídico-privadas que se vinculam à aquisição e alienação de propriedade, desempenham um papel essencial, Hegel parece com isso investir o paradigma jurídico-moral da justiça e do respeito recíproco à intangibilidade da pessoa de um papel extremamente significativo na manutenção de uma comunidade abrangente. Muito embora a esta intuição não seja dada a necessária consideração quanto ao seu vasto alcance - dentre outros motivos, porque Hegel se acha demasiado concentrado na crítica da positividade inerente ao legalismo (SIEP, $1976,51)$ - seu real significado se deixa medir negativamente pela revelação do caráter limitado do amor. "Um círculo do amor, um círculo de espíritos $<$ Gemütern $>$ que renunciam, um em face do outro, a seus direitos a tudo de particular e são somente unificados pela crença comunitária e esperança, cujos fruir e alegria são somente esta unanimidade pura do amor, é um pequeno reino de Deus.” (HEGEL, 1970, I, 407).

Amor e direito, enquanto formas paradigmáticas de intersubjetividade ou de relação comunitária, são compreendidos como opostos irreconciliáveis que possuem, todavia, um ponto em comum: ambos se revelam inadequados enquanto princípios absolutizados da integração social. Como mostra Hegel em sua discussão sobre a pena como destino, padecendo da positividade geral do legalismo, o direito, apego ao objetivo e ao domínio sobre as coisas, caracteriza-se, enquanto relação intersubjetiva, pela consideração do outro como separado, como objeto apartado ainda que intangível segundo a lei, o que, elevado à potência de princípio de integração social, converte-se, como mostrará Hegel na Differenzschrift, na compreensão da comunidade como máquina. Por outro lado, para o amor, o obstáculo nada mais é do que a formação lato sensu da individualidade. "A alegria dele [do amor E.C.L] se mescla com toda outra vida, reconhece-a, mas se recolhe ao ter o sentimento de uma individualidade" (HEGEL, 1970, I, 395).

Para Hegel, o destacamento das individualidades da unicidade vital das consciências pela sua formação, não somente enquanto Privatpersonen dotadas de direitos de propriedade e de intangibilidade, mas também seu cultivo enquanto Privatmenschen -, o que leva em conta o processo de individualização da consciência, a formação cognitiva e volitiva da

doispontos, Curitiba, São Carlos, vol. 4, n. 1, p. 63-106, abril, 2007 
personalidade na forma do engendramento de carências e interesses particulares -, é o elemento limitante do poder unificador do amor: "quanto mais individualizadamente <vereinzelter> se posicionam os seres humanos em relação à sua formação e ao seu interesse, em sua relação ao mundo, quanto mais cada um tem de característico <Eigentümliches>, tanto mais limitado o amor se torna a si mesmo". (HEGEL, 1970, I, 395) A insuficiência sócio-integradora do amor se mostra, por conseguinte, na necessidade de se recolher a um círculo de "ethos único" como forma de encontrar a satisfação que é seu estado de harmonia intersubjetiva e de unicidade da consciência: "para ter a consciência de sua felicidade, para dá-la a si mesmo, tal como ele faz com satisfação, é necessário que ele se aparte, que ele crie para si até mesmo inimizades." (HEGEL, 1970, I, 395) Com estas ponderações Hegel alcança então a precisão no seu diagnóstico das insuficiências do amor enquanto princípio sócio-integrador: "um amor entre muitos permite, portanto, apenas um determinado grau da força, da interioridade e exige igualdade do espírito, do interesse, das muitas relações de vida, esmorecimento das individualidades." (HEGEL, 1970, I, 395) Os efeitos da insuficiência do amor, especialmente o sectarismo e a renúncia à efetividade social, são exemplificados no comportamento de Jesus e seus discípulos. Entretanto, Hegel se lança a esta consideração não sem antes admitir que aglutinou à sua concepção de "vida ética", compreendida em Frankfurt ainda como amor, a necessidade de um nexo formativo ou participativo. Se, por um lado, o "legalismo" da nação judaica predomina de tal maneira que "a relação civilestatal <das staatsbürgerliche Verhältnis> diz respeito principalmente apenas à propriedade", e "o que se perde em quantidade de relações, em multiplicidade de vínculos felizes e belos, substitui-se pelo ganho em individualidade isolada e na consciência mesquinha de peculiaridades $<$ Eigentümlichkeiten > " (HEGEL, 1970, I, 399); por outro lado, o afastamento do séqüito de Jesus de toda participação na vida social e civil adquire já um sentido formativo de um Werden der Sittlichkeit. "Por causa do caráter da contaminação <Verunreinigung > da vida, Jesus somente podia trazer o reino de Deus no coração, somente [podia] entrar em relação com seres humanos para formá-los <um sie zu bilden> "(HEGEL, 1970, I, 399/400)

É certo que o fracasso do projeto hegeliano da Volksreligion, construído sobre a tradição marcante para Hegel da Vereinigungsphilosophie, não 
representa apenas a derrocada do ideal de juventude, mas sim o marco para o revigoramento das posições de Hegel com relação à filosofia social e o impulso para a construção do seu sistema da eticidade a partir de Jena: que a reconciliação exija suspensão do ponto de vista jurídicomoral, ou que o amor seja sectário, não invalida a possibilidade de que ambos os movimentos, a identidade e a diferença das consciências, sejam momentos de um processo de formação da consciência universal e de manutenção das individualidades.

A investigação em Frankfurt leva Hegel a perceber que, ao contrário da justiça, que é um ideal e um princípio de natureza argumentativa e discursiva, o amor não é capaz de fundamentar relações intersubjetivas de alcance mais amplo, nem de nadificar as cisões engendradas pelo direito e por uma socialização que se processa pelo paradigma da troca e da alienação de propriedade. No fecundo período de Frankfurt se encontram, portanto, as raízes da trajetória subseqüente da filosofia social de Hegel.A partir de Jena, Hegel verá como problema principal de sua teoria da eticidade a integração de relações intersubjetivas limitativas, as quais constituem o paradigma jurídico-moral do respeito recíproco e respondem também pela auto-afirmação da individualidade sob as condições de uma socialização que se processa com o advento da economia capitalista; e relações éticas solidárias, responsáveis por uma socialização positiva e pela formação de aspectos da personalidade que somente ganham seu sentido pleno no não isolamento e no "direito" da natureza pulsional estabelecido pela mediação do outro.

Neste novo quadro, ao amor é concedido um lugar contraposto às relações jurídicas, mas este é bem mais modesto e não traz a pretensão de promoção da integração social: a esfera da eticidade natural da família. Neste projeto de integração, pode-se dizer que os elementos de uma intersubjetividade solidária continuam a ser complemento da intersubjetividade limitativa, mas o fundamental é que o paradigma jurídico-moral também possa funcionar como complemento das relações intersubjetivas solidárias, sem o que tais relações se manteriam demasiado frágeis sob as condições do individualismo moderno. "Apenas o intercâmbio sob normas jurídicas, posto de maneira duradoura, entre indivíduos que agem complementarmente, torna a identidade do eu - a saber, a autoconsciência que se conhece na outra autoconsciência - instituição. Agir com base

doispontos, Curitiba, São Carlos, vol. 4, n. 1, p. 63-106, abril, 2007 
no reconhecimento recíproco é primeiramente garantido através da relação formal entre pessoas de direito" (HABERMAS, 1968, 811). A questão é saber até que ponto os dois paradigmas de intersubjetividade podem ser compreendidos como momentos de uma unificação abrangente (KOTKAVIRTA, 2004, 30). Parece-nos que, justamente para a fundamentação deste nexo, poder-se-ia apelar à educação no sentido de forjar a interface entre a unicidade de consciência e a individualização. Uma coisa parece, todavia, estar clara: é preciso integrar à concepção de intersubjetividade frankfurtiana de Hegel o "momento jurídico" da diferenciação dos indivíduos como momento positivo da consciência-de-si universal (SIEP, 1998).

\section{Educação e as diretrizes da constituição intersubjetiva do "Espírito do Povo" a partir de 1802}

Muito embora o Naturrechtaufsatz não enfatize - tanto quanto se poderia esperar, diante da expectativa gerada pela crítica a Fichte na Differenzschrift -, uma crítica aos aspectos limitativos e excludentes do direito enquanto relação intersubjetiva entre as vontades singulares, subjaz certamente à sua discussão do atomismo do moderno direito natural a compreensão do direito como um modo insuficiente de interação, "disseminado" no declínio da eticidade e, por conseguinte, pela imposição histórica de limites exíguos a formas solidárias de intersubjetividade: o direito natural moderno se vincula a uma compreensão da comunidade humana segundo o modelo da "unificação dos muitos", uma conexão dos sujeitos singulares isolados (HONNETH, 1992, 42/43).

Para Hegel, a contrapartida institucional da hipertrofia da esfera econômica da satisfação dos interesses particulares é, portanto, o "sistema de propriedade e direito", a imersão no "débil não tomar parte <Gleichgültigkeit> próprio à vida privada" (HEGEL, 1970, II, 492). Com efeito, "com esta vida privada universal e para o estado no qual o povo se constitui apenas do segundo estamento, está presente imediatamente a relação formal de direito, a qual fixa o singular e o põe absolutamente." (HEGEL, 1970, II, 491) 
Em face desta forma limitada de sociabilidade constituída pela defrontação dos indivíduos enquanto Eigentümer, é enunciada a bravura $<$ Tapferkeit>, a disposição em dar a vida pelo povo, como índice de um Einssein da vontade singular com a totalidade ética e, com isso, também de uma unificação ética dos indivíduos que constituem este povo. Há, portanto, um "choque" entre formas de relação intersubjetiva, ainda que escamoteada pela primazia da relação entre universal e singular, que revela a "obrigação" de risco de morte individual em nome do todo como não passível de coerção segundo o paradigma jurídico-moral do imperativo categórico (WILDT, 1983, 317). Assim compreendida, a prontidão para morrer pelo povo está em relação unívoca com o caráter ético de uma comunidade, a qual somente é genuinamente ética se aquela "obrigação" obtiver significado, ao passo que isto somente acontece, se as relações intersubjetivas em que o indivíduo (ao menos do primeiro estamento) se encontra são revestidas de um caráter não individualista. Eis porque Hegel empreende esta crítica, pelo conceito de bravura, à coercibilidade própria à moral do indivíduo e à intersubjetividade jurídico-privada, cujo objetivo é apontar para a suspensão da esfera individualista, mesmo em face da necessidade do direito privado na regulamentação da persecução dos interesses particulares.

Se, por um lado, Hegel localiza a "gênese conceitual" da eticidade absoluta na prontidão em morrer pelo povo, sua Ständelehre não deixa ver ainda a constituição da totalidade ética como suspensão de uma autoafirmação multilateral das individualidades, do processo histórico de destacamento dos indivíduos que caracteriza a modernidade, um movimento ao qual já Geist des Christentums submetera o poder reconciliador da unidade vital; e isto porque a Ständelehre no Naturrechtaufsatz, enquanto resultado do processo de auto-sacrifício do absoluto e de reconhecimento da necessária subsistência de sua porção inorgânica na modernidade - movimento pelo qual a eticidade absoluta "reconhece" (HEGEL, 1970, II, 494) o direito do inorgânico e "ao mesmo tempo dele se purifica" (HEGEL, 1970, II, 494) -, significa, em termos da organização interna do povo, a delegação, pelo próprio absoluto, dos papéis a serem desempenhados pelos indivíduos: ou o direito à vida e à persecução dos interesses e satisfação das necessidades no âmbito da esfera privada, ou a vida ética em sua plenitude, evidenciada na prontidão de se 
anular como indivíduo pelo bem do todo. "A tragédia está nisso, que a natureza ética, a fim de não se envolver com sua [natureza] inorgânica, aparta-a de si como um destino e a contrapõe a si e, através do reconhecimento do mesmo na luta, está reconciliada com a essência divina como com a unidade de ambos." (HEGEL, 1970, II, 496) Esta dificuldade de compreender a eticidade absoluta como engendrada pela suspensão da afirmação multilateral das individualidades, da "ubiqüidade do crime", reside principalmente no fato de que reconhecimento não é aqui ainda a gênese de uma universalidade intersubjetiva a partir do confronto entre indivíduos, mas o auto-movimento do absoluto (WILDT, 1983, 317-321; HABERMAS, 1974, 809/810).

Em face da identificação (HABERMAS, 1974), promovida no Naturrechtaufsatz, entre a relação ética - que em Frankfurt fora compreendida como restabelecimento da unidade intersubjetiva originária, rompida pela auto-afirmação individualista do "criminoso" - e o processo de auto-diferenciação do absoluto prático (MÜLLER, 2002), o System der Sittlichkeit efetua a re-assimilação da lógica da interação ao âmbito genuinamente interpessoal, pelo que a gênese da eticidade absoluta pretende integrar o momento próprio à modernidade de um destacamento "generalizado" das individualidades, da possibilidade de um conflito aberto em que todos os indivíduos são potencialmente "criminosos". Com efeito, o tema do crime e da luta se torna objeto da parte intermediária deste importante texto hegeliano, a qual, sob o título de "o negativo ou a liberdade ou o crime”, promove a negação e a ruptura do arcabouço de relações societárias e pré-estatais apresentado no primeiro capítulo, a "eticidade natural" ou "eticidade absoluta segundo a relação" (HONNETH, 1992, 25/26).

Do ponto de vista do direcionamento de Hegel à investigação do desenvolvimento conceitual da eticidade, o intento programático do Naturrechtaufsatz se deixa principalmente perceber na ausência de vínculo entre a exterioridade universal/singular e a exterioridade dos indivíduos enquanto átomos subsistentes por si, isto é, no fato de que não se ocupa com a questão de como, enquanto condição para o ser-um de liberdade universal e liberdade singular, os indivíduos são capazes, com base em nexos societários originários, não só de "instituir", em primeiro lugar, sua exterioridade mútua, como também de suspendê-la gradativa- 
mente em direção ao âmbito de uma autoconsciência universal e de um reconhecimento que conserva e ultrapassa a institucionalização da intangibilidade da pessoa, um âmbito capaz de combinar a universalização trazida por uma "socialização" tipicamente jurídica com a possibilidade de uma "individualização" potencialmente indeterminada (HABERMAS, 1988). Com a "tragédia no ético", o Naturrechtaufsatz privilegia, em sua tentativa de articulação do acolhimento da eticidade relativa na eticidade absoluta, a relação entre universal e singular, mas não a relação intersubjetiva propriamente dita, cujo desenvolvimento, a partir de formas originárias de formação recíproca de identidades individuais - concebidas a contrapelo da "individualização pronta" do contratualismo -, até um ponto em que se suspende a exterioridade mútua dos indivíduos, é o que pode constituir o tecido social da totalidade ética como povo. De fato, Hegel parece indicar, em sua crítica à tese fichteana da necessidade da coerção sob condições de rompimento de uma relação intersubjetiva "não excludente" (HEGEL, 1970, II, 471), que a suspensão da exterioridade recíproca se conecta com o ser-um originário, pelo que, entretanto, as "condições de possibilidade" da exterioridade e sua suspensão permanecem intocadas.

Apesar disso, alguma indicação neste sentido é fornecida na "tipologia das ciências práticas" oferecida pelo Naturrechtaufsatz. Em face do direito natural como ciência da eticidade absoluta real (HEGEL, 1970, II, 504/505), da ética como descrição da natureza das virtudes nos indivíduos do primeiro estamento, e da "moral deontológica" como ciência do potencial de expressão da eticidade universal na vida do burguês (CRUYSBERGS, 1986, 109), a educação tem em comum com as últimas a referência à subjetividade do indivíduo. "Assim como ... [a ética E.C.L] tem relação <Beziehung> ao subjetivo ou negativo, então o negativo em geral tem de ser diferenciado enquanto subsistir da diferença e enquanto falta $<$ Mangel $>$ da mesma ... a falta $<$ Mangel $>$ de diferença representa a totalidade enquanto um encoberto e não desdobrado $<$ Eingehülltes und Unentfaltetes $>$, no qual o movimento e infinitude não são em sua realidade." (HEGEL, 1970, II, 507/508) Desta maneira, enquanto na moral e na ética a negatividade aparece especificamente como diferença realmente existente, na educação a negatividade aparece, ao contrário, como falta de diferença, isto é, como uma diferença não-

doispontos, Curitiba, São Carlos, vol. 4, n. 1, p. 63-106, abril, 2007 
desenvolvida entre indivíduo e totalidade, uma indiferença imediata, já que se trata não da "realidade social" da infinitude, mas apenas da possibilidade do movimento que a possa pôr. "A criança é, enquanto forma da possibilidade de um indivíduo ético, um subjetivo ou negativo, cujo tornar-se humanizável (Mannbarwerden) é o cessar desta forma e cuja educação é a disciplina ou o subjugar da mesma." (HEGEL, 1970, II, 507)

Para Hegel, a criança a ser educada não se destacou ainda da totalidade, como aquele indivíduo que parece existir por si mesmo, quer como um átomo, quer como "homem público". Na criança, individualidade, a disposição moral e virtudes têm que ser desenvolvidas, pois a eticidade ainda não se manifesta como o espírito do indivíduo. "O positivo e a essência é que ela, sorvendo o seio da eticidade universal, primeiramente viva em sua intuição absoluta como um ser estranho, compreenda-a <begreift $>$ cada vez mais e passe, assim, para o espírito universal." (HEGEL, 1970, II, 507) Num significativo paralelo com a compreensão posterior do reconhecimento, Hegel compreende este processo de educação como o aprendizado gradual pela criança de suspensão da exclusividade de sua própria subjetividade (HEGEL, 1970, II, 507/508).

Tal compreensão da educação como gradual manifestação da eticidade no indivíduo originariamente indiferente, até o ponto de uma "indiferença mediatizada" entre o indivíduo e os costumes, suscita as mesmas questões dirigidas à concepção fichteana da Aufforderung como educação. Para elevar o indivíduo à manifestação da eticidade, como se poderia compreender isto como resultado apenas de uma relação limitativa e excludente aos outros indivíduos, se o indivíduo que se forma não é propriamente capaz de defrontar os outros enquanto subjetividade excludente? Uma tal compreensão da educação requer a participação dos outros indivíduos na formação da identidade e na individualização daquele sujeito que, originariamente, é imediatamente indiferente. Mas uma tal participação ativa somente pode ser pensada num paradigma de sociabilidade positiva e não excludente. Hegel parece indicar, então, que aqui sua filosofia prática se abre à compreensão deste processo de formação do indivíduo como contendo em si, além da forma de intersubjetividade própria ao defrontamento jurídico das pessoas, formas positivas da sociabilidade como sua condição.

doispontos, Curitiba, São Carlos, vol. 4, n. 1, p. 63-106, abril, 2007 
Deste modo, através do conceito de educação, delineia-se o desafio de um desenvolvimento conceitual da eticidade: mostrar como a intersubjetividade excludente, que se efetiva na esfera econômico-jurídica, consiste em um estágio insuficiente no itinerário que conduz à constituição de uma vontade universal como "identidade especulativamente estruturada" das vontades singulares, quer porque lhe faltem as condições de sua própria possibilidade (de uma individualização plenamente acabada), quer porque exceda seu escopo a suspensão da impenetrabilidade, a qual se vincula a formas socialmente abrangentes de cooperação. Com isso, torna-se mais claro como o problema da constituição da vontade universal a partir dos singulares diz respeito também à tematização das interfaces entre nichos de intersubjetividade responsáveis pela gradual integração dos singulares em níveis cada vez mais sofisticados de "consciência universal", interfaces que, como parece indicar Hegel, podem ser tematizadas a partir da relação dialética entre formas excludentes e participativas de intersubjetividade. Se, no Naturrechtaufsatz, a ênfase recai sobre a prioridade de eticidade absoluta sobre relativa, é o System der Sittlichkeit que vai articular, pela primeira vez, a teoria da eticidade moderna como esferas de uma gradativa constituição da identidade individual (HONNETH, 1992, 40 e seg.).

Hegel formula, inspirado em Fichte, a possibilidade de articulação de formas de intersubjetividade através da educação, ao basear sua recuperação moderna da anterioridade da comunidade política sobre o indivíduo na unidade originária das vontades singulares, concepção à qual ele opõe justamente sua constituição segundo o atomismo contratualista. Mas se à recuperação moderna da tese aristotélica subjaz uma compreensão da constituição originária e "pré-política" da comunidade, isto é, da unidade pré-política das vontades singulares, trata-se com isso fundamentalmente de uma concepção de intersubjetividade que se pretende radicalmente diferente da intersubjetividade limitativa e excludente. Se, em favor da reconciliação política, a eticidade relativa tem que ser integrada como momento da eticidade absoluta, o desenvolvimento da eticidade tem de incorporar, como um de seus momentos, a "defrontação" dos indivíduos enquanto proprietários e pessoas jurídicas (RIEDEL, 1974). Neste ponto surge, para Hegel, o problema da interface entre formas de intersubjetividade.

doispontos, Curitiba, São Carlos, vol. 4, n. 1, p. 63-106, abril, 2007 


\section{Educação como mediação entre Amor e Direito}

No System der Sittlichkeit, Hegel concebe, ainda ao nível da primeira potência da "eticidade absoluta segundo a relação", nexos intersubjetivos que colaboram para a formação de um estofo comunitário e societário, ainda que anterior à organização política, o qual possibilita aquela "institucionalização abstrata da individualidade" na forma de um respeito recíproco legalmente sancionado, a qual é a contrapartida da regulação jurídica da esfera econômica. Com efeito, dado seu Ansatz aristotélico de uma recuperação de formas societárias pré-políticas na organização política do estado (ILTING, 1974), Hegel agrega a seus motivos "frankfurtianos" sugestões provenientes do Naturrecht de Fichte (MEIST, 2002). Por um lado, Hegel assimila à sua concepção de formas societárias "naturais" o amor, restrito agora à estrutura da kleine Familie. Por outro lado, agrega ao estofo comunitário pré-político a concepção, sugerida por Fichte, de um paradigma de intersubjetividade não excludente, vinculado à "educação formativa" < Bildung > dos indivíduos (WILDT, 1983, 320 e 321).

O caráter pré-ético da "eticidade absoluta segundo a relação" não está na ausência de formas preliminares de uma individualidade intersubjetivamente mediada (GÖHLER, 1974, 384), mas antes no inacabamento das formas de unidade pelo predomínio da singularidade. Com efeito, a eticidade natural se compõe de estruturas sociais pré-políticas, isto é, anteriores, no contexto da "reconstrução", à universalidade concreta da eticidade substancial. Tais estruturas se desdobram em dois momentos: em primeiro lugar, fenômenos que primeiramente constituem a universalidade formal na interação e que se formam como a contraparte da relação concreta entre ser humano e a natureza (amor, formação recíproca das inteligências e vida em família); em segundo lugar, as estruturas socialmente abrangentes de uma universalidade formal que possibilita as relações econômicas e o intercâmbio jurídico entre os indivíduos. Este esquema geral de formas pré-políticas de existência intersubjetiva reproduz a polarização lógica das potências da eticidade natural.

Entretanto, devido ao problema "metodológico" da exterioridade entre o conteúdo das determinidades éticas e o desenvolvimento das potências $^{11}$, a conexão entre educação, luta e amor adquire uma feição 
bastante peculiar nesta obra. Ainda no ambiente "natural" e "intuitivo" da eticidade segundo a relação (sua primeira potência), da atividade produtiva ainda não tornada abstrata pela exigência social de satisfação generalizada das carências, Hegel alcança o conceito de inteligência como meio de trabalho e posse (HEGEL, 2002, 11). Hegel compreende a relação "viva" entre trabalho e produto como se realizando no meio universal que é a inteligência, de maneira que o trabalho vivo é, enquanto relação viva do elaborar e do objeto, essencialmente o trabalho intersubjetivo de formação no interior do gênero humano, mediante o qual é intersubjetivamente formada tanto a capacidade prático-cognitiva dos indivíduos, quanto sua natureza anímica individualizada.

A singularização da unidade natural não-desenvolvida, da relação unívoca entre sujeito e objeto estabelecida pelo trabalho vivo, convertese, para Hegel, numa estrutura sujeito-objeto que perpassa os diversos indivíduos. "O ser humano é potência, universalidade para o outro, mas o outro igualmente, e assim faz / da sua realidade, do seu ser peculiar <sein eigentümliches Sein $>$, do atuar sobre outro, uma acolhida na indiferença, e ele é agora o universal em face do primeiro.” (HEGEL, 2002, 11/12)

O trabalho vivo se efetiva no meio $<$ Mitte $>$ oferecido pela inteligência humana, pelo que a relação viva entre sujeito e objeto toma a feição de um trabalho recíproco de formação dos indivíduos, e a reconstrução do ético é reconduzida a uma interação universal entre os mesmos, que se constitui como possibilidade de sua existência social.A tese de Hegel é, portanto, que a potência do tornar-se ativo do indivíduo é elevada a uma atividade viva em que sujeito e objeto se complementam, e, sobre o fundamento da mesma, a atividade do particular eleva-se ao universal, torna-se mútua formação das inteligências. "E a formação $<$ Bildung $>$ é este permutar absoluto no conceito absoluto, no qual cada sujeito e universal transforma, ao mesmo tempo, absolutamente sua particularidade em universalidade e, em meio ao oscilar na posição momentânea como potência, põe-se a si mesmo justamente como universal; e, com isso, tem este ser-potência e a universalidade de maneira não-mediada no mesmo, em face de si, e, por conseguinte, torna-se ele mesmo um particular." (HEGEL, 2002, 12)

A cooperação na produção para satisfação de carências socialmente engendradas "ergue, sobre o ser-uma-com-a-outra das inteligências, uma totalidade própria” (KIMMERLE, 1968, 218), o trabalho como 
formação, enquanto um "absoluto permutar no conceito absoluto", no qual cada singular se torna sujeito e universal ao mesmo tempo, e torna sua particularidade imediatamente universal. Não por acaso esta transformação do conceito em seu oposto, sem que seja necessária sua aniquilação, é associada à inteligência (HEGEL, 2002,12), a qual ganha aqui, como o que é capaz de ser "imediatamente o contrário de si mesma", uma estrutura claramente intersubjetiva. Na medida em que interagem enquanto sujeitos, que são também objeto de uma elaboração mútua, os seres humanos apresentam cada qual a unidade imediata de opostos, isto é, como particulares sendo verdadeiramente para si, enquanto são, atuando uns sobre os outros, universais. O princípio da existência ética pré-política dos indivíduos é, então, a universalidade elevada à totalidade de inteligências que agem reciprocamente em prol de sua mútua formação $<$ Bildung $>$. Desta maneira, é pré-figurada, ainda no âmbito da naturalidade do gênero humano, a unidade real e a universalidade socialmente abrangente da totalidade ética no povo. Eis porque esta potência alcança sua efetivação mais concreta na fala $\langle$ Rede $\rangle$, a mediação mais concreta dos sujeitos que interagem.

O resultado da submissão do "trabalho de formação" ao movimento das potências é, através da relação entre pais e filhos enquanto meio de unificação de "uma relação social ‘sem desejo` que se direciona à dissolução” (SCHNÄDELBACH, 2000, 85), a interação universal e formação recíproca dos seres humanos, uma unidade individualizante de idealidade e realidade que se pretende interpretar aqui, seguindo Schnädelbach, como uma "socialização pré-institucional e pré-política de seres humanos que cooperam entre si” (IBIDEM). Em seguida, a remanescente "separação" das inteligências é suspensa pelo sentimento sem diferença do amor. "A aniquilação da forma própria é recíproca, mas não absolutamente igual. Cada um olha a si mesmo no outro, como [sendo] ao mesmo tempo um estranho, e isto é o amor." (HEGEL, 2002, 13) Esta unidade dos diferentes no sentimento, a qual, para Hegel, é apenas momentânea, torna-se presença intuitiva com a relação entre os mesmos e os filhos, nos quais, através do trabalho de formação, o particular se torna universal:

"a determinidade dos contrapostos é uma [determinidade] superficial, não natural, real, e o prático se dirige, na verdade, à suspensão desta 
determinidade contraposta, porém não em um sentimento, [mas] antes de tal maneira que ela se torna intuição de si mesmo em um estranho e, por conseguinte, tem seu desenlace com a individualidade acabada que se lhe defronta <mit gegenüberstehender vollkommener Individualität endigt $>$, através do que o ser-um na natureza é suspenso ainda mais. Esta é a relação de pais e filhos.” (HEGEL, 2002, 13)

Esta relação, que culmina na formação de uma individualidade plenamente acabada e antecipa a formação da sociedade civil a partir da dissolução da família nas Grundlinien ${ }^{12}$, é revestida de um papel sui generis no System der Sittlichkeit, na medida em que esta relação passa a ser um momento necessário da "reconstrução do ético" e, com isso, também um estágio imprescindível de uma socialização que se processa ainda segundo a naturalidade do mesmo, a qual se torna assim condição para formas institucionalizadas de existência social dos indivíduos como pessoas. "O ser-um absoluto de ambos separa-se imediatamente na relação. A criança é o ser humano subjetivo, mas de tal maneira que esta particularidade é ideal, um exterior é somente a forma. Os pais são o universal, e o trabalho da natureza se dirige à suspensão dessa relação, tal como o [trabalho] dos pais, os quais suspendem cada vez mais a negatividade exterior da criança e, justamente por meio disso, põem uma negatividade interior ainda maior, com isso, [uma] individualidade mais elevada." (HEGEL, 2002, 13) Portanto, Hegel concebe uma forma societária "natural” ou "pré-política" que unifica processos de socialização e a individualização (HONNETH, 1992, 28), cujo nexo formativo é o verdadeiro Werden der Sittlichkeit ${ }^{13}$.

No System der Sittlichkeit, amor e formação recíproca encontram sua identidade na criança: no trabalho das inteligências umas para com as outras, o meio $<$ Mitte $>$ é um vivo, a criança. "A totalidade do trabalho é a individualidade perfeitamente acabada < die vollkommene Individualität $>$ e, com isso, igualdade dos contrapostos, no que a relação é posta e suspensa, adentra, aparecendo, no tempo, todos os instantes e se inverte no contraposto, segundo o acima descrito: [é a] interação universal e formação dos seres humanos." (HEGEL, 2002, 13) A formação é agora o trabalho com respeito aos outros sujeitos, isto é, o produzir da subjetividade nos outros indivíduos. Seguindo o conceito fichteano de 
Aufforderung, Hegel compreende a formação como processo de interação pelo qual os sujeitos formam uns aos outros enquanto sujeitos. $\mathrm{O}$ trabalho recíproco de formação dos sujeitos é, na medida em que forma uma relação entre sujeitos que mantém a diferença, parte do estofo intersubjetivo através do qual a eticidade pode se fazer efetiva. $\mathrm{O}$ amor e a educação são o núcleo das formas naturais de intersubjetividade não excludentes enunciadas por Hegel ${ }^{14}$, a relação ética do "conhecer-se no outro" e o processo de formação da individualidade ${ }^{15}$, momentos que Hegel vê apenas potencialmente unificados na relação entre pais e filhos: "cada um é um ser igual e autônomo <ein gleiches, selbstständiges Wesen>. Que também a relação / de tal amor e sensação seja, é forma exterior, a qual não diz respeito à sua essência, que é a universalidade em que eles se encontram.”(HEGEL, 2002, 13/14)

Hegel concebe estas estruturas segundo o modelo de um “(re)conhecer" imediato, imediato porque não supõe o conflito, a partir de onde poderia se erguer como sua extirpação: "um reconhecer que é recíproco, ou a suprema individualidade e a diferença exterior." (HEGEL, 2002 , 13) Entretanto, amor e educação formativa são relações intersubjetivas dependentes da singularidade, e como a eticidade absoluta exige a suspensão do singular na unidade e na universalidade, amor e educação são insuficientes enquanto formas genuinamente éticas de existência comum (HEGEL, 2002, 13). Tal como acontece com o reconhecimento formal da pessoa, também tais formas intersubjetivas precisariam de uma realidade duradoura, de uma "presença absoluta". Entretanto, ao contrário da universalidade formal da regulação jurídica da esfera econômica, nas formas intersubjetivas inclusivas da naturalidade do ético, a universalidade está oculta por detrás dos indivíduos, não aparecendo a eles como universalidade formal que se encontra acima deles e os subordina: nisto reside a "espontaneidade" das formas não excludentes de relação intersubjetiva.

Na segunda potência da "eticidade natural", a universalidade, ainda determinada pela singularidade e ainda não manifesta como universalidade determinante e duradoura, emerge da interioridade e passa a exercer a função de coordenação, em condições sociais mais abrangentes, das relações recíprocas entre os agentes. Em vista das relações naturais recuperadas na primeira potência, este movimento toma a feição de uma fixação das mesmas em relações econômico-jurídicas, na qual a 
contingência inicial é subordinada ao controle pelo universal. Entretanto, a esfera econômica juridicamente regulada tem, em comum com o estágio imediato da naturalidade do ético, sua permanência no âmbito da mera relação à particularidade, pela qual ela mesma lhe aparece também como uma particularidade. "A relação de troca e do reconhecimento da posse, e, com isso, a propriedade - a qual se referiu até aqui a singulares torna-se aqui totalidade, mas sempre no interior da própria singularidade, ou seja, a segunda relação é assimilada à universalidade, ao conceito da primeira."(HEGEL, 2002, 27)

No movimento de passagem do momento natural ao momento conceitual na "idealidade" ou "formalidade", o universal vai se tornando paulatinamente a idealidade do indivíduo, a qual era, na esfera natural da relação, prefigurada pelo aparecimento ainda particularizado do universal da linguagem (KIMMERLE, 1968, 223). Este ponto marca a entrada dos indivíduos numa relação "excludente" e "atomizada" de uns para com os outros. Uma primeira forma desta relação é a necessária cooperação atomizada na produção e na satisfação universal das carências.

Quando a orientação desta atividade produtiva não é mais a orientação natural pela satisfação de carências singulares, mas a relação do indivíduo ao trabalho excedente e, por conseguinte, à satisfação generalizada de carências, impõe-se a condição de que estes indivíduos atomizados e subordinados a uma relação mecânica de produção se reconheçam entre si como possuidores de maneira universalmente válida, sem o que a orientação voltada ao uso dos produtos do trabalho pelos outros, e que é fornecida pelo excedente, não poderia ter lugar: a subsistência do universal socialmente abrangente impõe a condição do reconhecimento da posse como propriedade, pelo que a atividade econômico-produtiva revela sua face jurídico-legal. "O sujeito não é meramente determinado enquanto um que possui <als ein Besitzendes>, mas assimilado à forma da universalidade, enquanto um singular em relação a outros e universalmente negativo, enquanto um que possui e é reconhecido <als ein anerkanntes Besitzendes>." (HEGEL, 2002, 21) Ao se reconhecerem como possuidores, os indivíduos se reconhecem mutuamente como produtores de algo a partir da natureza sobre cuja disposição eles, enquanto compaginações individualizadas das forças singulares empregadas na produção, erguem pretensões de utilização. "Posse é, nesta perspectiva, propriedade

doispontos, Curitiba, São Carlos, vol. 4, n. 1, p. 63-106, abril, 2007 
$<$ Eigentum $>$. A abstração da universalidade na mesma é, todavia, direito $<$ Recht>." (HEGEL, 2002, 21)

$\mathrm{Na}$ entrada dos indivíduos, na forma excludente da singularidade absolutamente para si, em uma rede socialmente abrangente de relações, é estabelecida a correspondência entre o direito privado e a concepção negativa da liberdade individual, à qual subjaz a diferença absoluta do particular em face do universal, o que torna esta construção da liberdade individual numa relação intersubjetiva excludente, antecipando o mote hegeliano na apresentação do direito abstrato nas Grundlinien, uma espécie de ficção incompleta, ainda que necessária ao funcionamento da economia de mercado própria à era moderna. "O indivíduo é proprietário, possuidor legal < rechtlicher Besitzer> não é absolutamente, em e para si: sua personalidade ou a abstração de sua unidade e singularidade é simplesmente uma abstração e uma coisa-de-pensamento < Gedankending >." (HEGEL, 2002, 21) Neste percurso, é demonstrada a tese hegeliana, trazida do Naturrechtaufsatz, segundo a qual propriedade e direito são dois lados da mesma moeda (SCHNÄDELBACH, 2000, 84). A economia, ou seja, a subordinação da atividade produtiva à "lógica" do excedente, não pode ser pensada sem o direito de propriedade, isto é, sem o reconhecimento socialmente abrangente da posse. $\mathrm{O}$ direito privado regula a interação entre indivíduos atomizados mediada por suas relações às coisas, isto é, as reivindicações intersubjetivas erguidas com respeito à posse.

A esfera econômica juridicamente regulada, em que os singulares se deparam uns com os outros em relações de troca contratualmente asseguradas, pressupõe, enquanto esfera de uma unidade desta idealidade que adquire presença, uma relação intersubjetiva como seu sustentáculo; "pois o reconhecer é o ser-singular < das Einzelnsein>, a negação, de maneira que ela permaneça como tal fixada, embora seja ideal, em outros: é simplesmente a abstração da idealidade, não a realidade neles." (HEGEL, 2002, 21) Assim, às relações intersubjetivas naturais, como a formação mútua enquanto sujeitos cooperativos no trabalho, a linguagem e as relações entre homem e mulher e entre pais e filhos - as quais antecipam, na intuição recíproca de si mesmo no outro própria da eticidade absoluta, a realidade do conceito absoluto como intuição - sucedem-se as relações intersubjetivas “idealmente presentes" ou "institucionalizáveis", pelas quais os sujeitos se reconhecem enquanto reconhecidos e regulados pelo direito.

doispontos, Curitiba, São Carlos, vol. 4, n. 1, p. 63-106, abril, 2007 
1 Traduzimos este termo tanto por interpelação, procurando manter o nuance intersubjetivo, como por solicitação, tencionando manter o sentido final da abordagem, isto é, o instar o outro a demonstrar sua liberdade.

2 Seguimos aqui Honneth. "O que Fichte reproduz aqui na forma de um regresso infinito, deixa-se apresentar, ao se distanciar de suas próprias palavras, também na figura de uma aporia, na qual toda aquela explicação da consciência-de-si, que se utiliza do modelo da reflexão auto-referente (Modell der selbstbezüglichen Reflexion), tem de cair.” (HONNETH, 2001, 70)

${ }^{3}$ A interpelação preenche as características de um ato da consciência pelo qual o sujeito finito faz a experiência de si mesmo como sujeito prático e teórico, atuante sobre um objeto e também determinado por si mesmo. Este ato da consciência não é o ato próprio da consciência transcendental que tem de ser pressuposta na Wissenschaftslehre pela posição do eu puro, da qual se explica o saber de si mesmo como determinado pelo não-eu (SIEP, 1992, 49). O conceito de Aufforderung é vinculado, neste sentido, explicitamente à dedução transcendental das condições necessárias da consciência-de-si, às quais pertence também a gênese da consciência da individualidade. (Bartuschat, 1992, Verweyen, 1975 e Zaczyc, 1992).

${ }^{4}$ Decerto, há que se conceder a Honneth que "Fichte não pode ter pretendido compreender seu conceito de interpelação no sentido estrito de um imperativo, porque com isso seria subtraída ao endereçado a tomada de posição propriamente tencionada; ele deve ter escolhido este conceito específico para salientar a circunstância de que, em toda abordagem (Anrede) de um outro ser humano, está contida uma exigência $\langle$ Zumutung $\rangle$, na medida em que dele está sendo esperada uma reação condizente a um ser capaz de razão." (HONNETH, 2001, 76). É certo também que, no âmbito em que Fichte constrói o argumento não é necessário sobrecarregar a interpelação com conotações morais. Mas, como o próprio Honneth reconhece, a interpelação possui implicações normativas: "todo ser humano que aborda seu próximo de forma comunicativa, obriga-se, na execução do ato de fala, a conceder-lhe ao menos a possibilidade de uma resposta não-coagida. Inversamente, pode-se, com bons motivos, esperar daquele que, através da abordagem, se tornou o endereçado, uma reação que consiste no uso de sua própria capacidade racional." (HONNETH, 2001, 77)

${ }^{5}$ A percepção de si como uma pessoa atuante no mundo sensível, o qual, segundo os $\$ \S 3-4$, contém também a existência de outros seres racionais atuantes, somente pode surgir, se pertence à pessoa uma esfera de atuação de sua liberdade disponível somente a ela. É esta esfera de atuação da liberdade que constitui o caráter individual da pessoa. Para Fichte, nesta auto-atribuição de uma esfera individual de liberdade reside a passagem originária do eu formal absoluto para o eu material, determinado pela contraposição em que atribui a si uma esfera diferente do mundo para a atuação pessoal da liberdade. Tal passagem ocorre pelo contraste entre a egoidade fundamental, enquanto intuição pura da atividade infinita, e o eu individual como pessoa determinada concretamente pela sua presença no mundo sensível, a qual faz, na auto-posição a partir da consciência prática comum, a experiência de si mesma como ser racional. (FICHTE, 1971, 57)

6 Interpretamos a interpelação como acontecimento que suscita, no interpelado, uma atitude performativa em relação ao outro, uma abertura à alteridade cujas potencialidades alcançam a possibilidade de cooperação e de uma relação positiva à vontade do outro. Para Siep, o Naturrecht se caracteriza pela introdução, no método de dedução transcendental, de elementos refe-

doispontos, Curitiba, São Carlos, vol. 4, n. 1, p. 63-106, abril, 2007 


\section{2}

rentes à experiência da consciência, o que lhe permite interpretar as passagens entre os $\$ 3 \mathrm{e}$ $\$ 4$ e entre o segundo e terceiro Hauptstücke como contínuas. Contestando a posição de Verweyen (VERWEYEN, 1975) e Baumanns (BAUMMANS, 1972, 175), segundo a qual uma interpelação somente se deixa pensar como relação de reconhecimento recíproco, Siep insiste na tese de que, por ser um ato de educação, a interpelação não é de maneira nenhuma redutível a uma atuação conforme ao "comportamento jurídico", isto é, ao respeito indiferente à esfera de liberdade, já que se trata de uma atuação sobre um indivíduo que ainda não "chegou", em geral, à consciência de si. Isto permite a conclusão de que a interpelação nem inclui nem pressupõe o reconhecimento (SIEP, 1991, 57).

7 Para Falke, a tarefa da "verdade da certeza de si mesmo" consiste em realizar o princípio especulativo da filosofia fichteana através de uma crítica imanente, de maneira a reconduzir a subjetividade isolada, que se absolutiza neste enunciado, à consciência da racionalidade do efetivo. Para isso, segundo Falke, Hegel entra em um embate com textos fichteanos que vão desde a Grundlage des Naturrechts, passando pela Sittenlehre e chegando até a Bestimmung des Gelehrten. (FALKE, 1996, 143)

8 Sobre a distinção kantiana entre o "amor patológico" e o "amor prático", Kant compreende o mandamento de "amor a Deus" como "fazer os próprios deveres com satisfação" (KANT, 1968, IV 148,V 13). Na Doutrina da Virtude, o "amor prático" adquire, enquanto "máxima do bem-querer", importância também na esfera do agir intersubjetivo (KANT, 1968, VI 118). Neste sentido, amor seria um sentimento que acompanha a execução de deveres morais para com os outros e que, na situação específica da obrigação moral intersubjetiva, poderia ser visto como diferenciação do respeito.

${ }^{9}$ Antes mesmo que Hegel atinasse com a possibilidade de afastamento em relação a Kant, Hölderlin formulara, já em 1795, uma crítica da filosofia prática de Fichte como dominação da natureza pela razão, e mesmo do caráter puramente antropológico da ampliação do belo kantiano operada por Schiller (WYLLEMAN, 1989). Para Hegel, é extremamente importante a concepção de um ser <Sein> como unificação <Vereinigung > que antecede o juízo $<$ Urteil $>$ ou a partição originária $<$ Urteilung $>$ que engendra sujeito e objeto. (BONDELI, 1997)

10 Ao utilizar o conceito de Bildung para se referir ao processo de condensação da individualidade destacada da eticidade substancial, Hegel parece compreender este processo como contendo mais elementos do que aqueles que convergem para a origem do Privatmensch a partir do declínio da pólis antiga, o que corresponde, nos contornos gerais, à tese de Lukàcs sobre os escritos de Frankfurt (LUKÀCS, 1986). Para Lukàcs, somente no período de Frankfurt aparece para Hegel o problema de uma avaliação positiva das instituições modernas, da sociedade burguesa e do indivíduo privado.

11 (SCHNÄDELBACH, 2000, 82), (HONNETH, 1992, 33), (GÖHLER, 1974) e (LEIJEN, 119 e seg)

12 Contestamos, complementando Schnädelbach (2000, 86), que, de acordo com os Entwürfe über Religion und Liebe, esta seja a primeira exposição desta intuição hegeliana. Schnädelbach também não vê que, no System der Sittlichkeit, o "motivo fundamental da teoria hegeliana da socialização” (IBIDEM) está literalmente presente. O movimento, que faz convergir a relação entre pais e filhos e o processo de formação recíproca, processo que eleva a particularidade à

doispontos, Curitiba, São Carlos, vol. 4, n. 1, p. 63-106, abril, 2007 
universalidade do gênero, é caracterizado como "um reconhecer que é recíproco, ou a suprema individualidade e a diferença exterior.” (HEGEL, 2002, 13)

13 Partindo do conceito de Werden da eticidade, mencionado por Hegel na tipologia das ciências práticas no Naturrechtaufsatz, principalmente com respeito ao papel a ser desempenhado pela educação, Honneth sustenta que somente se o Werden der Sittlichkeit pode ser compreendido como um "movimento de ir para dentro uma da outra" de socialização e individualização, é que "se pode, como seu resultado, aceitar também uma forma de sociedade que tem sua conexão orgânica no reconhecimento intersubjetivo da particularidade de todos os singulares.” (HONNETH, 1992, 28)

14 Como Honneth se dirige à tentativa de "expor", a partir de Hegel, um "conceito formal de eticidade", ele insiste numa sobreposição dos níveis, os quais se diferenciam principalmente no tocante ao elemento de identidade pessoal que, em um certo nível de existência intersubjetiva, encontra sua confirmação. Entretanto, pensamos que esta sobreposição ainda não faz totalmente justiça às potencialidades do modelo hegeliano (HONNETH, 1992, 33/34). Por isso, interessa-nos visualizar a complementaridade de socialização e individualização não simplesmente na sobreposição, mas sobretudo nas interfaces entre os níveis de reconhecimento recíproco, já que estas interfaces podem indicar as rupturas mais significativas na formação da identidade pessoal.

15 O System der Sittlichkeit prefigura as potências pelas quais se efetiva o espírito no Systementwurf 1803/1804, a potência da linguagem, do instrumento e da família, cuja irredutibilidade umas às outras e ao movimento de auto-reflexão do espírito foi defendida por Habermas. A concepção hegeliana a respeito da "fala" poderia ter servido de sustentáculo à importante tese habermasiana de que a "linguagem penetra no agir comunicativo... Mas também o agir instrumental, tão logo ele aparece como trabalho social, está inserido numa rede de interações e, por isso, é, por sua vez, dependente das condições comunicativas de contorno de toda possível cooperação.” (HABERMAS, 1974, 803).

\section{Referências Bibliográficas}

BARTUSCHAT, W. 1992. Zur Deduktion des Rechts aus der Vernunft bei Kant und Fichte. In: KAHLO, M. - Fichtes Lehre vom

Rechtsverhältnis. Frankfurt am Main: Klostermann

BONDELI, M. 1997. Der Kantianismus des jungen Hegel. Die KantAneignung und Kant-Überwindung Hegels auf seinem Weg zum philosophischen System. Hamburg: Felix Meiner

BOURGEOIS, B. 1986. Le Droit Naturel de Hegel (1802-1803) Commentaire. Paris:Vrin 
104

CRUYSBERGS, P. 1986. Hegel's critique of modern natural law. In: WYLLEMAN, A. Hegel on the ethical life, religion and philosophy (17931807). Louvain: Louvain University Press

FALKE, G. 1996. Begriffene Geschichte. Das historische Substrat und die systematische Anordnung der Bewußtseinsgestalten in Hegels 'Phänomenologie des Geistes'. Interpretation und Kommentar. Berlin: Lukas-Verlag FICHTE, J. G. 1971. Werke in 11 Bände. Berlin: Walter De Gruyter HABERMAS, J. 1974. “Arbeit und Interaktion. Bemerkungen zu Hegels Jenenser 'Philosophie des Geites””. In: GÖHLER, G. Frühe politische Systeme. Frankfurt am Main: Ullstein.

HEGEL, G.W.F. 1995. Enciclopédia das Ciências Filosóficas. São Paulo: Loyola.

2006. Linhas Fundamentais da Filosofia do Direito. Tradução de Marcos Lutz Müller (texto em fase de publicação, gentilmente cedido pelo tradutor)

. 2002. System der Sittlichkeit [Critik der Fichteschen Naturrechts], Hamburg: Felix Meiner . 1970. Werke in 20 Bände. Frankfurt am Main: Suhrkamp. HEIMSOETH, H. 1923. Fichte. München:Verlag Ernst Reinhardt. HONNETH, A. 2001. "Die transzendentale Notwendigkeit von Intersubjektivität (Zweiter Lehrsatz $\int$ 3)”. In: MERLE, J. Johann Gottlieb Fichte. Grundlage des Naturrechts, Berlin: Akadademische Verlag. 1992. Kampf um Anerkennung. Zur moralischen Grammatik sozialer Konflikte. Frankfurt am Main: Suhrkamp.

JAMME, C. 1988. Ein ungelehrtes Buch. Die philosophiesche Gemeinschaft zwischen Hölderlin und Hegel in Frankfurt 1797-1800. Bonn: Felix Meiner

. 1990 “'Jedes Lieblose ist Gewalt'. Der junge Hegel, Hölderlin und die Dialektik der Aufklärung”. In: JAMME, C. Der Weg zum System. Materialien zum jungen Hegel, Frankfurt am Main: Suhrkamp. 
KANT, I. 1968. Kants Werke - Akademie Textausgabe. Berlin: Walter de Gruyter.

KERSTING, W. 2001. "Die Unabhängigkeit des Rechts von der Moral (Einleitung ): Fichte Rechtsbegründung und 'die gewöhnliche Weise, das Naturrecht zu behandeln"”. in: MERLE, J. Johann Gottlieb Fichte. Grundlage des Naturrechts. Berlin: Akademische Verlag. 1993. Wohlgeordnete Freiheit: Immanuel Kants Rechts - und Staatsphilosophie. Frankfurt am Main: Suhrkamp.

KIMMERLE, H. 1970. Das Problem der Abgeschlossenheit des Denkens. Hegels „System der Philosophie“ in den Jahren 1800-1804. Bonn: H. Bouvier KOTKAVIRTA, J. 2004. “Liebe und Vereinigung”. In: MERKER, B. Subjektivität und Anerkennung. Frankfurt am Main: Mentis.

LAUTH, R. 1962. "Le Problème de l'interpersonalité chez J. G. Fichte". Archives de Philosophie, 25 , pp. 325-344.

LEIJEN, A. 1986. "The intituition of the absolute concept in the absolute ethical life: Hegel's System of Ethical Life”. In:WYLLEMAN, A. Hegel on the ethical life, religion and philosophy (1793 - 1807). Louvain: Louvain University Press.

LIMA, E. C. 2006. Direito e Intersubjetividade: eticidade moderna em Hegel e o conceito fichteano de reconhecimento. Campinas. 293 p. Tese de Doutorado em Filosofia, UNICAMP.

LUKÀCS, G. 1986. Der junge Hegel und die Probleme der kapitalistischen Gesellschaft. Berlin/Weimar: Aufbau-Verlag.

MEIST, K. 2002. Einleitung. In: G.W.F Hegel, System der Sittlichkeit [Critik des Fichteschen Naturrechts]. Hamburg: Felix Meiner.

MÜLLER, M. 2002. "O direito natural de Hegel: pressupostos especulativos da crítica ao contratualismo”. In: Filosofia Política. Rio de Janeiro, 5, 41-66.

RIEDEL, M. 1969. "Hegels Kritik des Naturrechts”. In: RIEDEL, M. Studien zu Hegels Rechtsphilosophie. Frankfurt am Main: Suhrkamp. 
1974. "Die Rezeption der Nationalökonomie”. In: GÖHLER, G. Frühe politische Systeme. Frankfurt am Main: Ullstein.

SCHNÄDELBACH, H. 2000. Hegels praktische Philosophie: Ein

Kommentar der Texte in der Reihenfolge ihrer Entstehung. Frankfurt am Main: Suhrkamp.

SIEP, L. 1979. Anerkennung als Prinzip der praktischen Philosophie. Freiburg/München: Alber.

.1992. “Einheit und Methode von Fichtes „Grundlage des Naturrechts"“". In: SIEP, L. Praktische Philosophie im deutschen Idealismus, Frankfurt am Main: Suhrkamp.

. 1998. Die Bewegung des Anerkennens in der Phänomenologie des Geistes. In: KÖHLER, D. G.W.F Hegel, Phänomenologie des Geistes, Berlin: Akademische Verlag.

VERWEYEN, H. 1975. Recht und Sittlichkeit in J. G. Fichtes Gesellschaftslehre. München: Alber.

WEISCHEDEL, W. 1973. Der frühe Fichte: Aufbruch der Freiheit zur Gemeinschaft. Stuttgart: Frommann-Holzboog.

WILDT, A. 1983. Autonomie und Anerkennung. Hegels Moralitätskritik im Lichte seiner Fichte-Rezeption. Stuttgart: Klett-Cotta.

WYLLEMAN, A. 1989. Driven Forth to Science, in: WYLLEMAN, A. Hegel on the ethical life, religion and philosophy (1793 - 1807). Louvain: Louvain University Press.

ZACZYC, R. 1992. "Die Struktur des Rechtsverhältnisses (\$S1-4) im Naturrecht Fichtes”. In: KAHLO, M. Fichtes Lehre vom Rechtsverhältnis. Frankfurt: Klostermann. 